\title{
تهافت الفلسفة النقدية
}

\section{م.م. عبدالجواد عبدالرزاق}

كلية 1لآداب / جامعة واسط

السمقدمهة

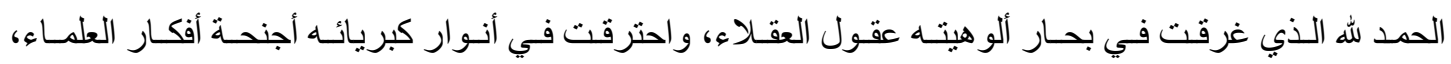
و الصلاة و السلام على خير الرسل والأنبياء، محهد وآله الطاهرين الأتقياء، وبعـــ. احتلت الفلسفة النقدية للفيلسوف الألماني عمانؤيل كنط (1724-1804) مكاناً بـارزاً في الفلسفة الغربيـة لعمقهاو دقتها، اضافة الى سعة مديات تأثنير ها في الفكر الفلسفي للغرب. اهتم كنط، بدر اسة وتحليل أصل المفاهيم المعرفيـة، ذلك لأن الفكر البشري يرتكز في عملياته الذهنية وفعالياته

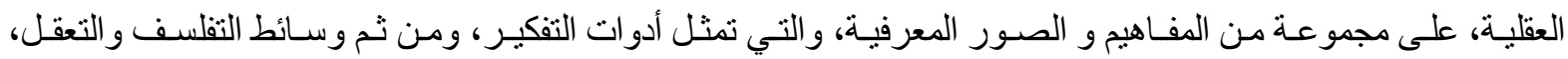

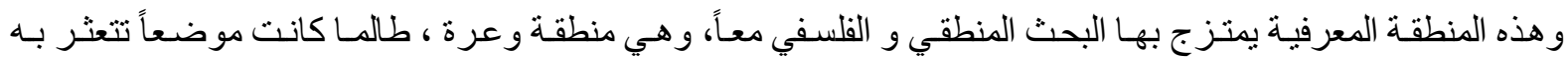
محاو لات الفلاسفة ، ومنزلقاً تتهاوى عند اعتابه النظريات . فجـاءت جهود كنط، شديدة الحذر عاليـة الدقة، وقلمـا كـان يهتم، و هو في خضم تحليلاته، بنسج أسلوب واضـح

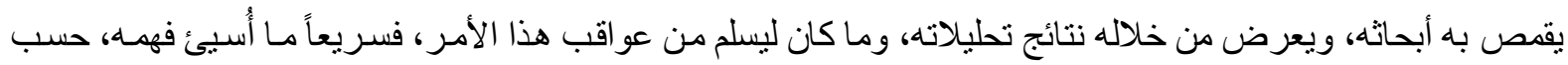

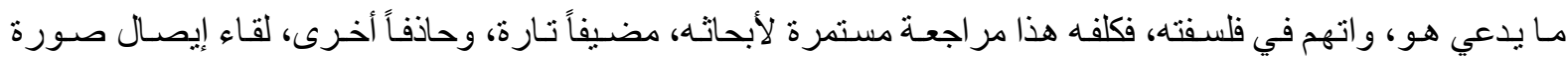

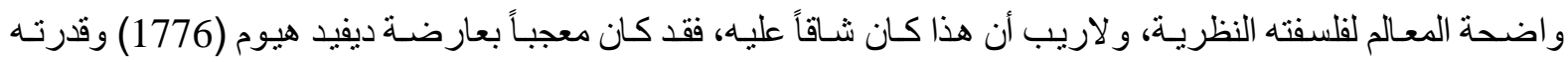
على تصوير أفكارهمن غير لبس أو غموض.

يتعامل العقل البشري، مع العديد من المفاهيم والأفكار، و هي ليست على وتيرة واحدة، أو نسق خـاص، من جهة

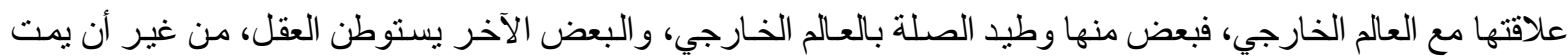
بصلة مباشرة مع العالم الخارجي، ففـاهيم من قبيل (الوجوب، الإمكان، النوع، و الجنس) ليست كمفاهيم (الجبل، السماء،

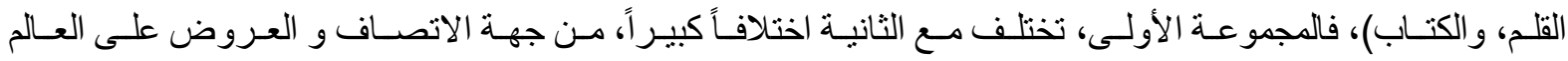
الخارجي.

ويصب كنط جهوده على تحليل ودر اسـة تلكـ المفـاهيم ذات الطـابع العقلي البحت، و التـي لا تشـوبها من حيـث التكوين، شائبة حسِ أو تجربة، ويسميها كنط بالمفاهيم العقلية المحضـة، و على هذا جاء عنوان كتابه (نقد العقل المحض) أي تحليل المفاهيم العقلية المحضة، والبحث عن أساس وجودها، لقاء معرفة الحدود المدكنة للعقل البشري.

و المشكلة الأساسية، تتمثل في كيفية نشـأة هذه المفـاهيم في لوح العقل، فهل هي ذاتية فيـه، كمـا عليه المـذهب

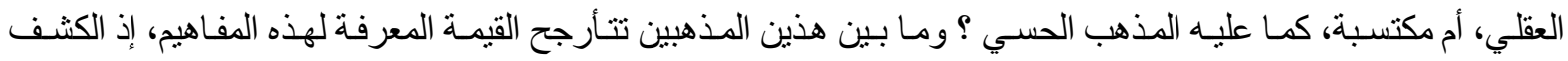

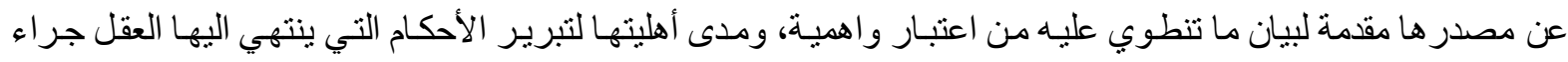

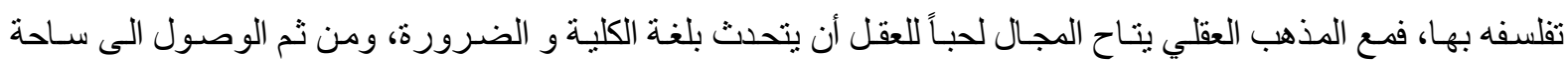

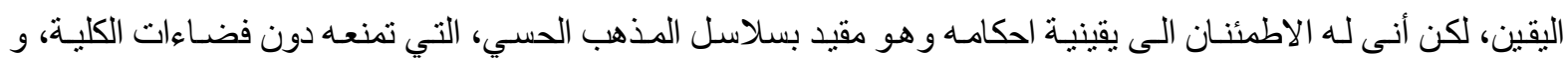


آفاق اليقين، ليبقى في بر اثن الثكوك، التي لاتغني عن الحق شيئا، هكذا وجدها كنط، مفاهيم تتجاذبها المذاهب الفلسفية، في صراع فكري كبير.

إلا أن الأمر كان مختلفاً تماماً في الفلسفة الإسـامية، والتي بلغت أوج رقيها، تز امنـاً مع بدايـة الفلسفة الحديثة في

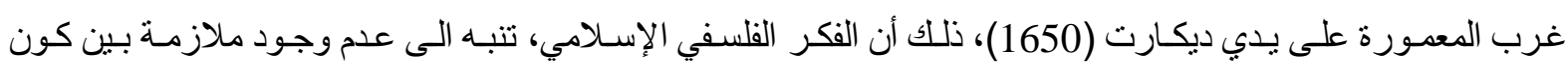

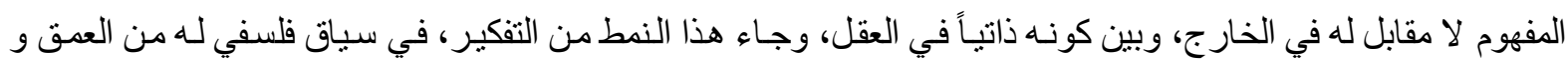

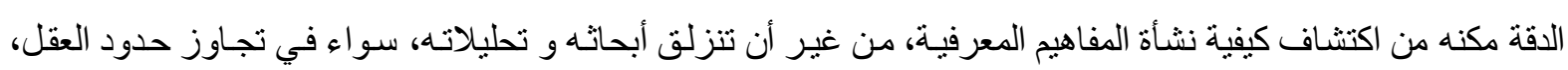

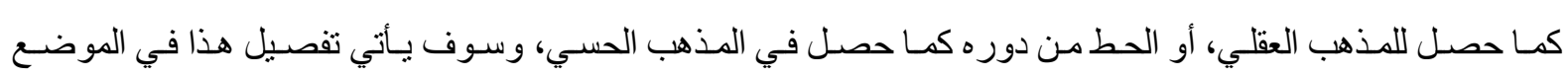
المناسب.

لم يقنع كنط، في كلا المذهبين، العقلي و الحسي، فليست أسس المعرفة في رأيه مركوزة في العقل، كمـا أنها

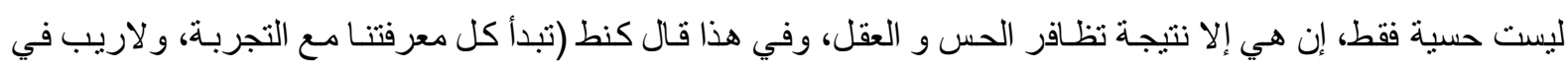
ذللك البتة ... لكن على الرغم من أن كل معرفتنا تبدأ مع التجربة، فأنها مع ذلك لا تنبثق بأسر ها من التجربة) '. لكن كيف استطاع كنط، أن يوفق في نظريته بين المذهبين، و هل نجح في ذللك ؟ و الوقوف على حقيقة الحسال

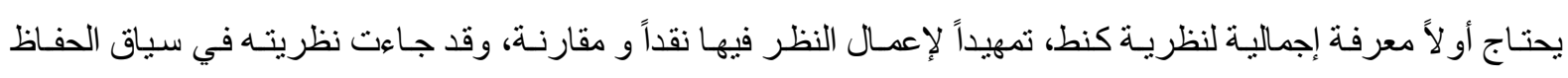

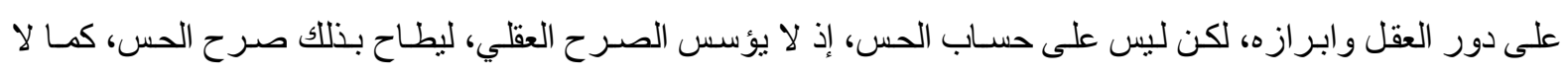
يرفع من شأن الحس لينحط بذلك شأن العقل ك.

بداية يقسم كنط، القضايا الى قسمين، في تقسيم يراه البعض مبتكر اً عنده، وهو :

أولاً : القضايا التحليلية.

ثانياً : القضايا التأليفية.

أمسا التحليليـة فهي تلك القضـايا التي يتضـمن موضوعها محمولها، أي أن المحمول فيهـا ليس إلا أمـر ذاتي في الموضوع، وتسمى أيضاً بالقضايا التكرارية، إذ المحمول يستخرج من صقع الموضوع، كقولنـا (المثلث شكل) فالثكلية،

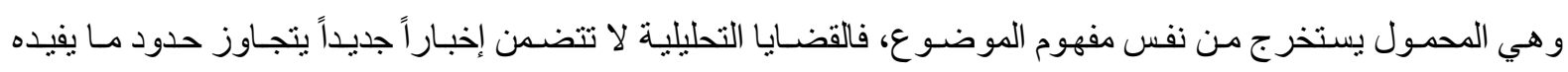

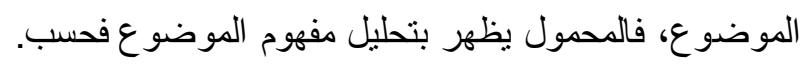

وتمتاز هذه القضايا، بأنها لا تحتاج الى غبر مبدأ عدم التناقض للتأكد من صحتها، قـال كنط (سيكون من الخلف

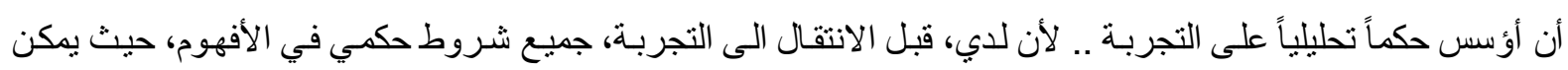
أن استخرج المحمول من مبدأ التناقض وحسب) '، وهذا اللون من القضايا، يكون قبلياً، ومعنى قبليته أي أنه ليس مستمداً

من التجارب و الخبرة الحسية، بل كان بمعزل عنها.

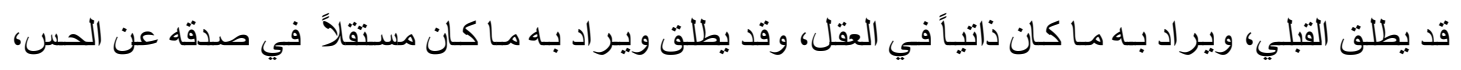

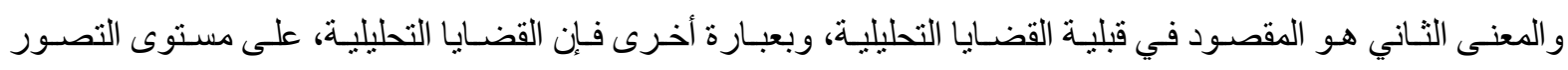
مكتسبة، أما على مستوى التصديق فلا.

أمـا القضـايا التأليفيـة، فهي تلك القضـايا التي لا يكون المحمول فيها متضـنـاً في موضـو عها، أي أن محمولهـا يو سع دائرة القضية معرفياً، ويضيف أمر اً جديداً لم يكن الموضوع بتضمنه، أو يتوفر عليه من ذي قبل، وتسمى أيضـاً 
بالقضايا الإخبارية، كونها تخبر عن أمر جديد، كقولنا (السماء تمطر) إذ مجرد تصور السماء، لا يفيدنا بهطول المطر، وفي هذا اللون من القضايا لا يمكن تحكيم مبدأ عدم التناقض للتأكد منها. ويرى كنط، ان القضـايا التأليفيـة، قسمان: أو لاً: القضـايا التنأليفيـة القبليـة، ثانياً: القضـايا التأليفيـة البعديـة كُ، وهذا تقسيم مبتكر أيضاً كما يعتقد الكثير، و الجديد فيه، هو القول بقضايا تأليفية قبلية.

\section{القضايا التأليفية القبلية.}

ويعني بقليتها، ذاتيتها في العقل، فهي لم تكتسب جر اء الخبرة الحسية، ويرى كنط ملكية العقل البشري لهكذا

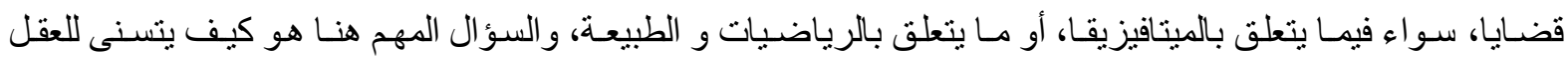

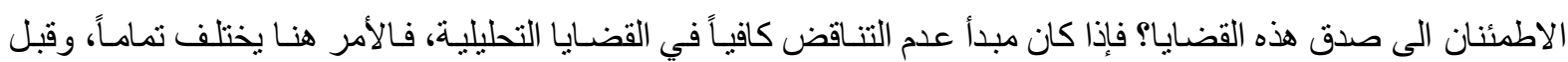
معرفة موقف كنط من هذا، هنالك أمور يجب توضيحها، من قبيل ماهية هذه القضـايا، و موقعها في العقل، ومدى قدرتها في تبرير المعرفة البشرية.

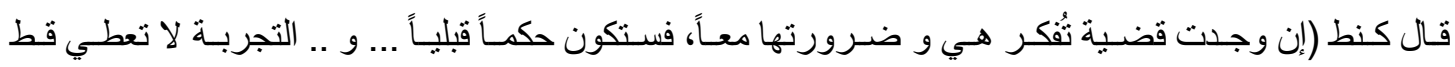
لأحكامها كلية) ، هنا يحدد معالم القضية التأليفية القبلية، فهي تحتوي على ونى عنصرين غير موجودين في الخارج، وبالتـالي

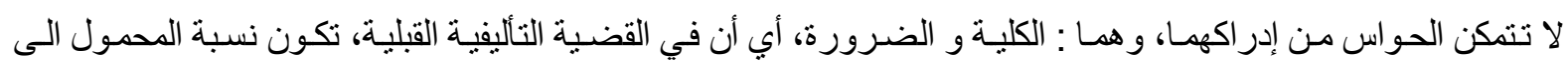

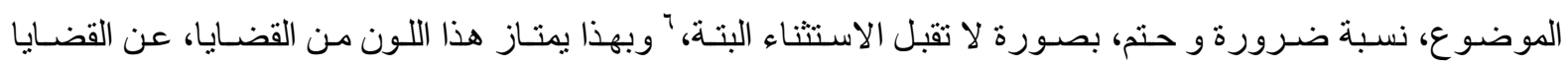
التحليلية، بأن محمولها ليس متضمَن في موضوعها، وعن التأليفية البعدية (التجريبية) بأنها لم تستمد من الخبرة الحسية. يـرى كنط، أن جميع العلوم النظريـة، تنضـن قضـايا تأليفيـة قبلية، بوصفها مبـادئ، و الى هذا الحـد يبدو كنط

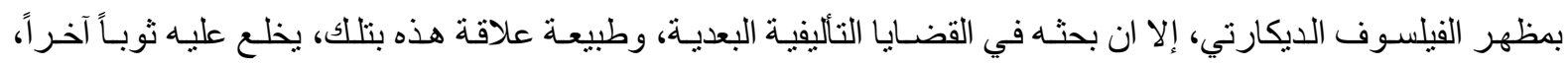

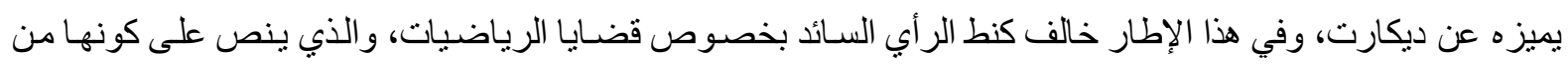

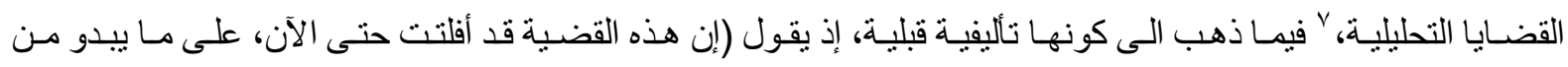

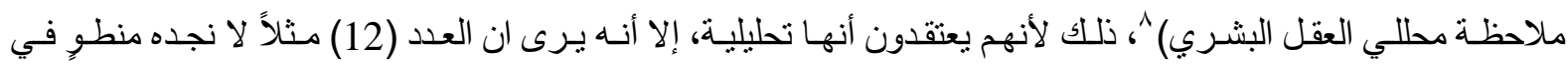

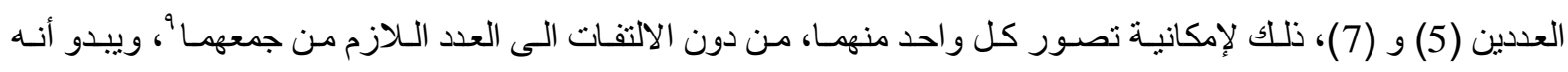
يشترط في القضايا التحليلية، بسـاطة الموضوع، الذي يستخرج منه المحمول عن طريق التحليل، وهذا الثرط مفقود في قضايا الحساب.

ومن جانب آخر، وهو جانب التسويغ الميتافيزيقي، يحدد كنط مجموعة من القضـايا التأليفية القبلية، و أهمها (مبدأ العلية) و الذي ينص على ضرورة وجود سبب لكل حادث، وهو بهذا يخالف ديفيد هيوم، ولم يكن موقف الأخير، إلا نتيجة وهنة الغلو في الاعتماد على الجانب الحسي، والجهل بفعالية العقل ودورها في المعرفة وهرد البشرية. بيد ان هذه القضايا، رغم أهميتهاو ضرورتها في البناء المعرفي لدى كنط، إلا انه يميز بين مستوبين لها، فتارة

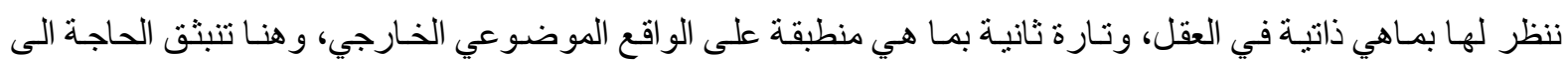

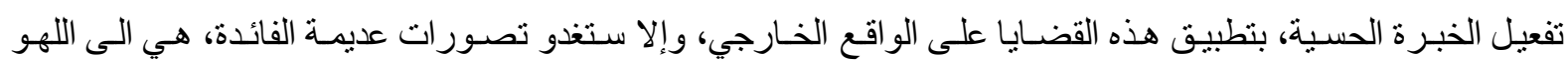

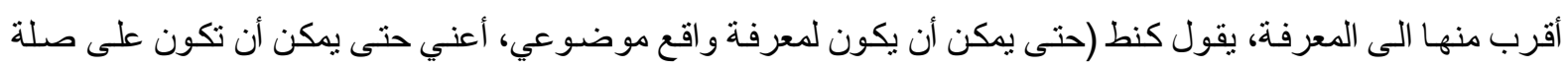

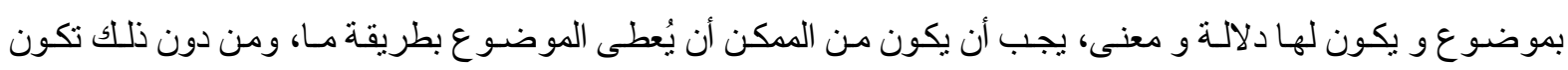


الأفاهيم فارغة ... فإمكان التجربـة هو إنن مـا يعطي جميع معارفنـا القبلية واقعاً موضوعياً) ' ، وهذا الجانب كما يسميه كنط : التسويغ المتعالي، وهنا تأتي أهمية القضايا التأليفية البعدية.

\section{القضايا التأليفية البعدية.}

ان البحث في القضـايا التأليفيـة البعديـة، يـرتبط مـع العـالم الخـارجي، والخبرة الحسية، أكثر مهـا هو مـع العقل

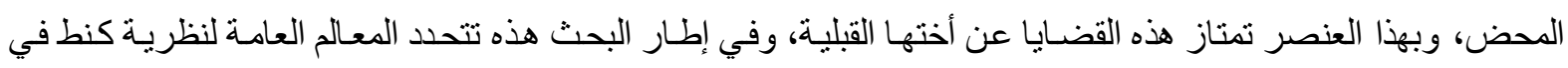

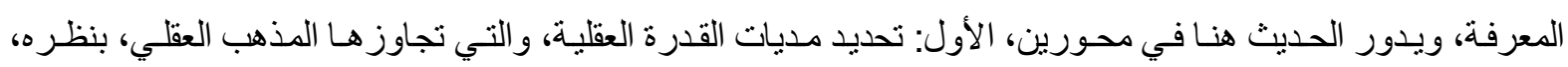
الثاني: رفض المثالية الاحتمالية لديكارت، والمثالية الذاتية لباركلي (1753).

الأول: يميز كنط، بين الحساسيةو الفهم (الذهن) '" ومن ثم بين مـادة المعرفة وصورتها، أمسا الحساسية فهي القدرة على تلقي التصور ات التي تـأتي من العـالم الخـارجي، فهي الجسر الر ابط بين عـالم العقل، وعـالم الخـارج، والقنـاة

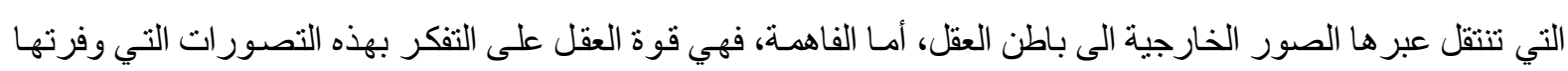

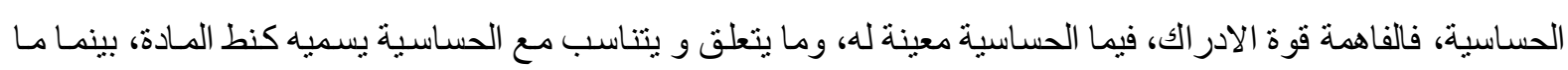

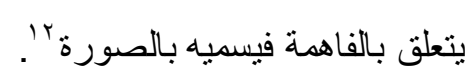
سبق أن أكد كنط على وجود قضـايا تأليفيـة، لم تتكون بفعل الخبرة الحسبة، وكـان في موقفه ذالك تجـاوب مـع المذهب العقلي، لكنـه مـا لبث حتى أعلن عن عدم كفايتها في تكوين هرم المعرفة، وهنـا يعود ليدلل على وجود مفاهيم لم

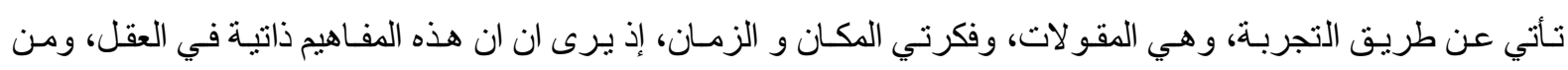

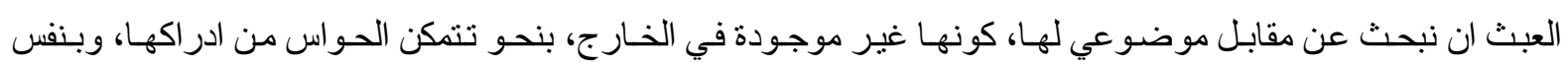

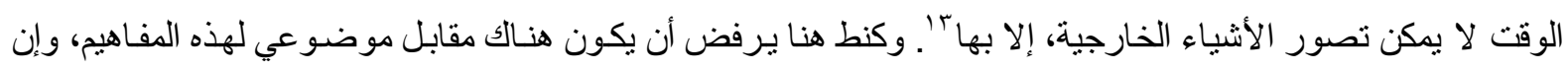

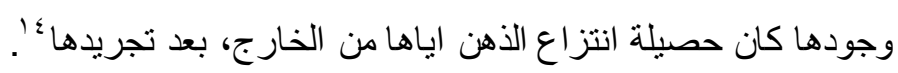
وخلافاً للفلسفة المشائية، التي تعد الزمـان و المكان من جملة المقو لات ْ ، نجد كنط يعزل الزمان و المكان، عن

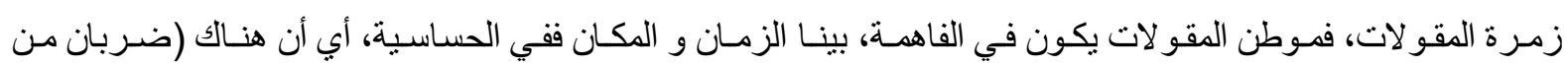

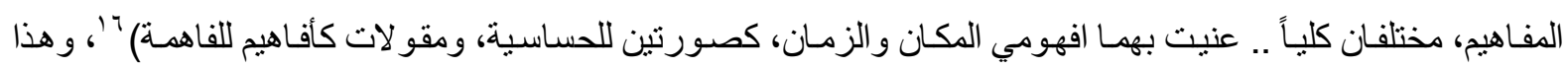

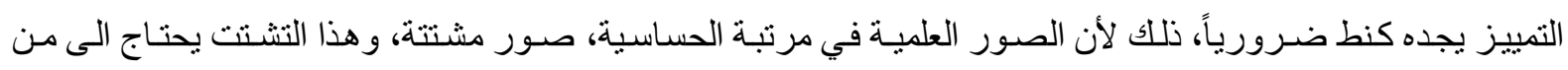
يجمعه وينسقه، إذن نحن بحاجـة الى دور جديد، لا يمكن للحساسية أن تؤديـه، كونها تقتصـر على التلقي و الانفعـال، أمسا

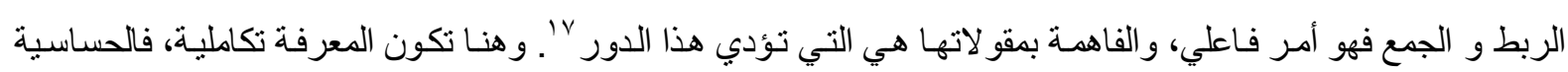

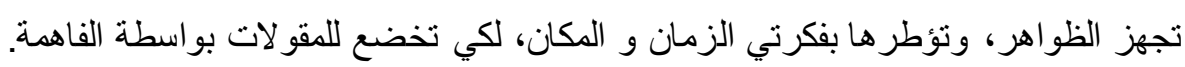
و هنا يرى كنط أن المعرفة لكي تنت، لا بد لها من أمر برزخي بين الفاهـة و الحساسية، مسانخ لكليهمـا، يُكَكن

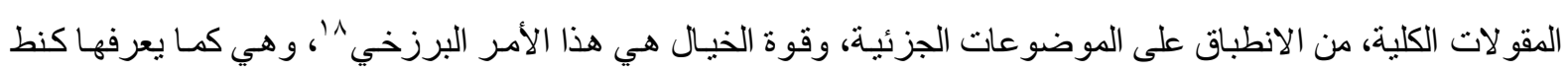
تبعاً للمشهور (قدرة تصور موضوع حتى من دون حضوره) 19. الثاني: إذا كانت القضـايا التأليفيـة، تعنمد على جانب قبلـي في العقل، وهو الصـورة، و على جانب بعدي و هو

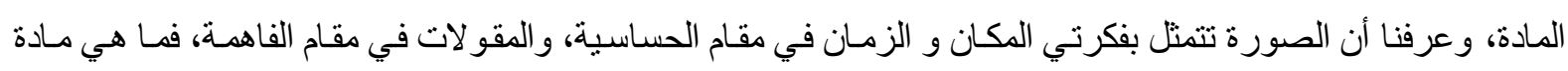
المعرفة ؟ يقول كنط (إن كل حدسنا ليس سوى تصور للظاهرة، وإن الأشياء التي نحدسها، ليست في ذاتها على مـا نحو 


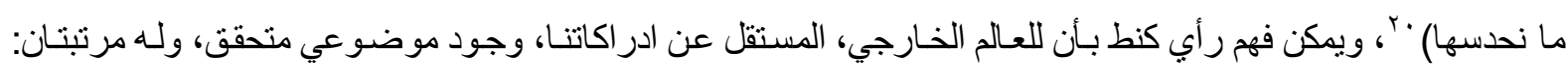
مرتبـة البـاطن، ويسميها كنط الثـيء في ذاته، أي كنهـه و حقيقته، ومرتبـة الظـاهر ، و الأولى عصية على على الادر الك، فيمـا

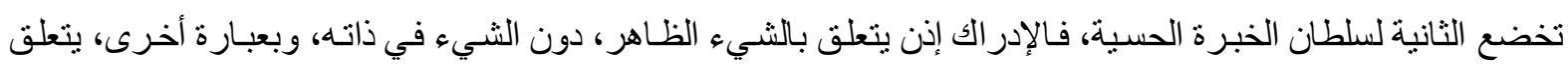
بظاهره دون كنه حقيقته.

و لا ريب في عدم قطعية هذا الفهم، فقد حصل خـلاف حول مر اده من الثـيء الظـاهر بَ، فهل ينتمي الى عـالم

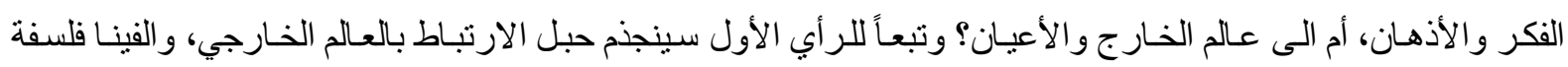

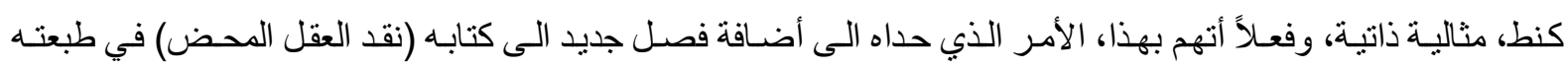

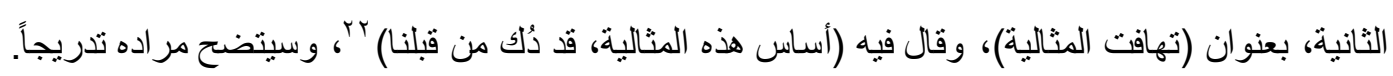

و هنـا وجد كنط نفسـه ملزمـاً بإثبـات العـالم الخـارجي، فقـال (يدلل مجرد الوعي بوجودي الخـاص، وعيـاً متعينـاً

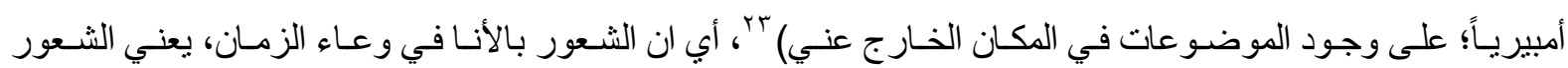
بلو ازمه كالتعاقب، والحالات المتغيرة التي تكون للأنا، ويرى كنط أن التعاقب و التغير من الأمور المتضـايفة، نظير الأبوة

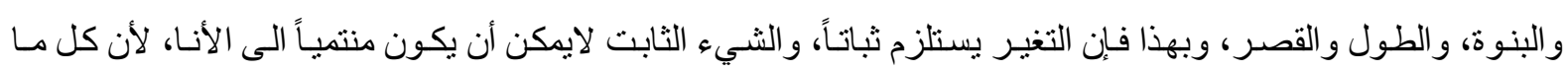

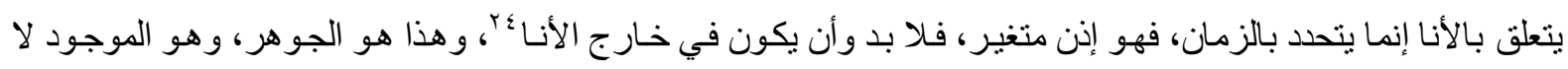

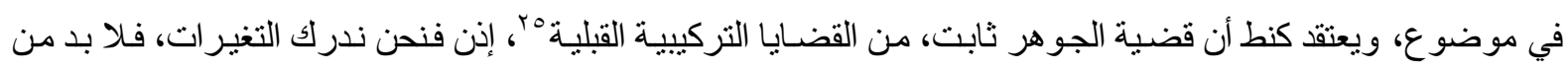

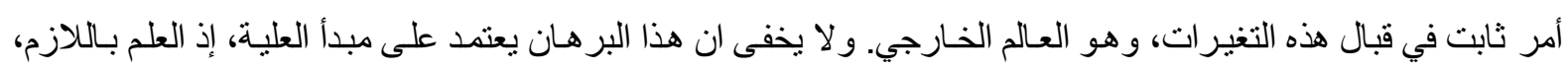
علة للعلم بالملزوم، وهذا منهج إني يعتمد على المعلول في إثبات العلة.

\section{موقف كنط من الميتافيزيقا.}

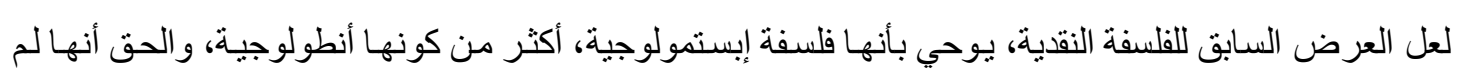
تبحث الجانب الأول إلا تمهيداً لموقف لا بد أن يتخذ إزاء الأنطولوجيا، فنقد العقل المحض، لكنط، كتاب في الميتافيزيقا،

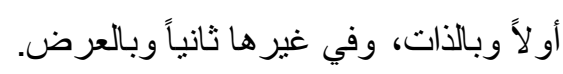
قال كنط (ان الأفاهيم الفاهمية [ الذهنية ] المحضـة، لا يمكنها قط، بمعزل عن كل شروط الحساسية، ان تصور

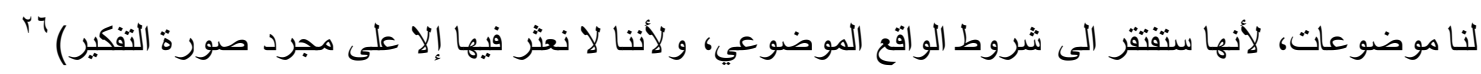
اتضح مدـا سبق أن كنط وضع شروطاً عامـة للمعرفة الصحيحة، تمنلت بالجانبين القبلي الصوري، و البعدي المادي، والأول يعتمد على ما هو ذاني، والثاني على مـا هو موضوعي، وبهذا فكل معرفة لا تشتمل على هذين الجـانبين،

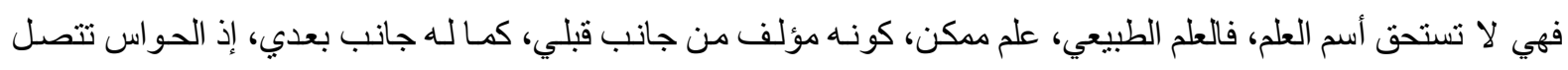

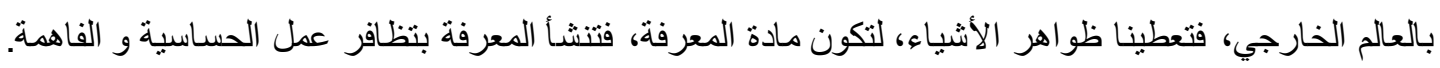
وفي هذا السياق يـرى كنط، ان العقل البشري، عـاجز تمامـاً عن معرفة القضـايا الميتافيزيقية، لأنسه يحتاج في

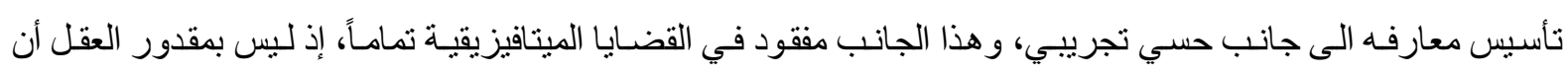
يتعامل تعاملاً تجريبياً مع قضايا من قبيل : واجب الوجود، خلود النفس، الخ..، من قضايا ما وراء الطبيعة. وتبعاً للهرم المعرفي الذي شيدته الفلسفة النقديـة، فمن المحـال إقامـة البرهـان على الوجود الإلهي، وان كل الأدلة

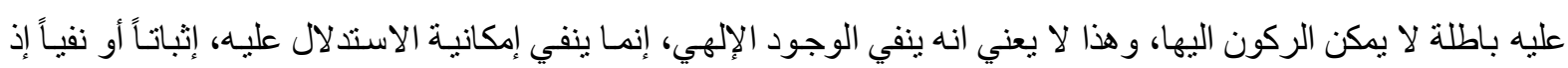


يقول (ان الاسباب نفسها التي ترينا عجز العقل البشري في موضع اثبات وجود مثل هذا الكائن؛ ستكفي بالضرورة أيضـاً

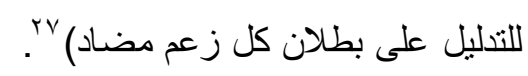

ويرى كنط ان الفلاسفة حساولوا عبنـاً وضع البراهين، فكانت ثلاثة لا غير، وهي : البرهـان الوجودي، وبرهـان الحدوث، وبرهان النظم، وهذه كلها بنظره عديمة الجدوى، نعم يبقى الدليل الأخلاقي قائماً.

نقد الفلاسفة النقديةمبr.

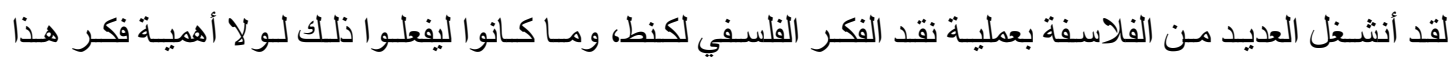

الفيلسوف، إذ النقد لا يعني التقليل من شأن الأفكار، بقدر ما يحكي عن الهم المعرفي، الذي يدفع بالإنسان نحو الحقيقة. و سيتمحور الحديث هنا على نقد الفلسفة الكانطية، في ضوء الإنجازات الفكريـة للفلسفة الإسلامية، بمنهج التحليل

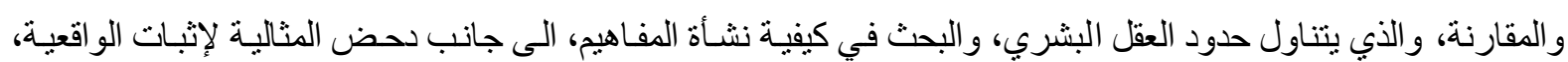

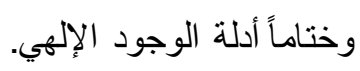

المسألة الأولى هنـا، تختص بمـا قالله كنط، في تقسيم القضـايا، إذ يرى ان القضـايا قسمان، تحليلية، وتركيبيـة،

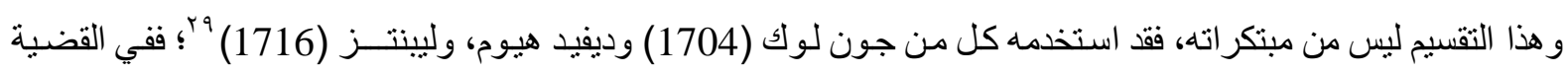

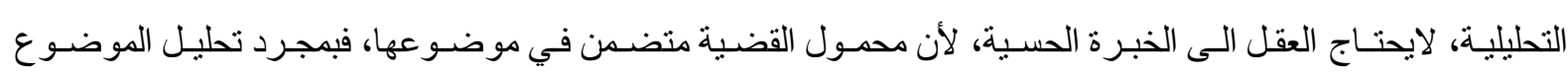

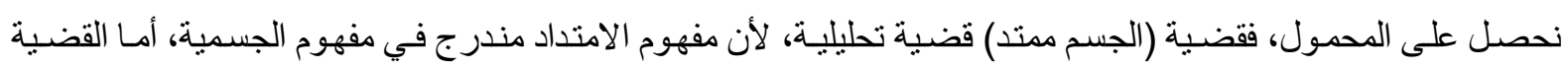

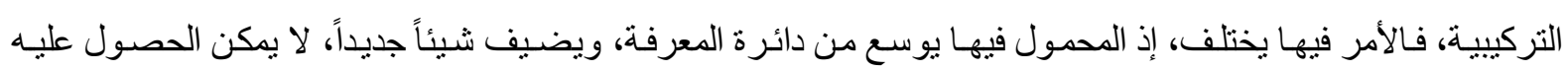
بمجرد تحليل الموضوع، وهنا تتحتم مسألة الرجوع الى الخبرة الحسية. وبهذا فإن العقل بمجرد تجـاوزه القضـايا التحليلية، يفقد قدرتهـ الذاتية في الحكم، فيستعين بـالخبرة الحسية ليتمكن من ممارسة دوره، ولما كانت القضايا التحليلية مجرد قضايا تكرارية، وإن القيمة المعرفية، تكمن في القضـايا التركيبية، فإن سلطان الخبرة الحسية، سيعلو على سلطة العقل.

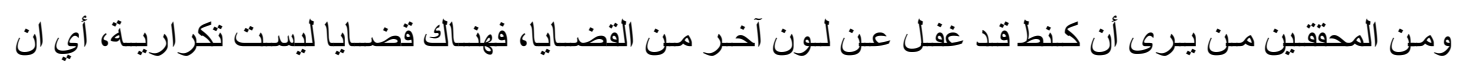

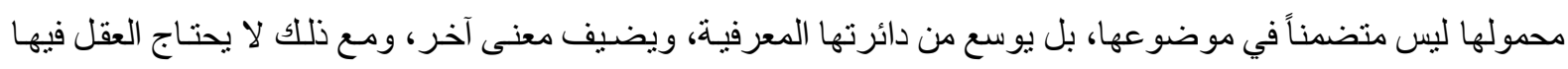

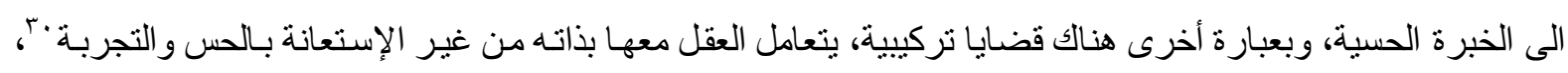

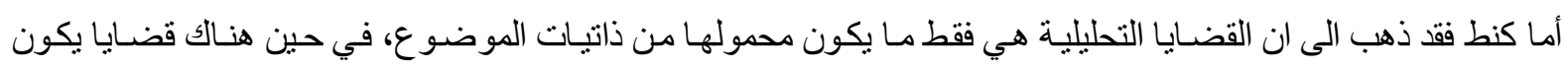
المحمول فيها من اعر اض الموضوع، لا من ذاتياته، ومع ذللك فالعقل لا يحتاج الى الخبرة الحسية في إثباته. ولتوضيح هذه المسـألة لا بـد من التمييز بين معنيين للذاتي، الأول يصطلح عليه بالذاتي في بـاب إيسـاغوجي

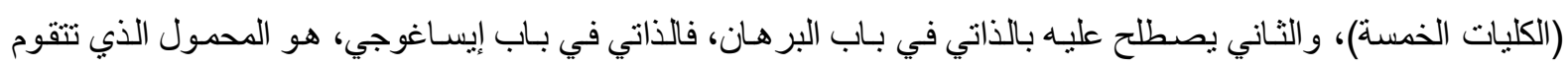

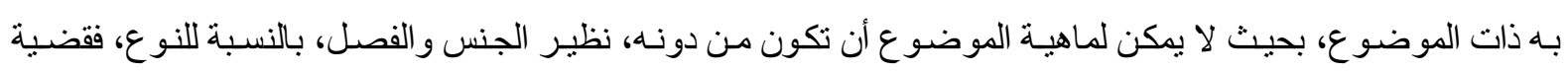
(الانسان حيوان نـاطق) كان محمولها ذاتياً لموضو عها، إذ الموضو ع، متقوم بمحموله، وهذه القضـايا هي قضـايا تحليلية

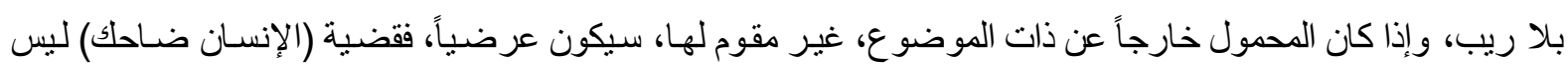

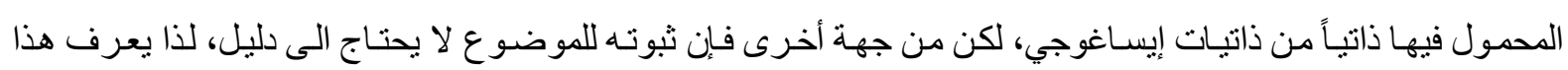

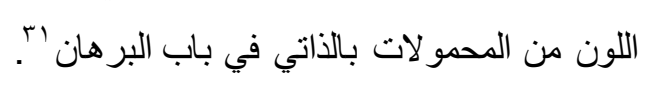


و الذاتي في بـاب البرهـان، لا يعد من مقومـات الموضـوع، بقدر مـا هو من لواحقه، وهنـا قيل إن القضية التـي

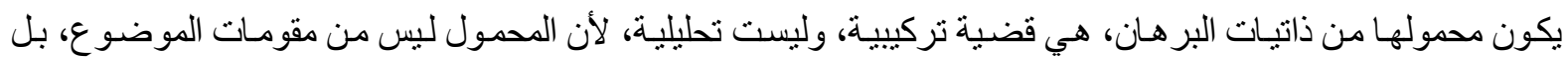

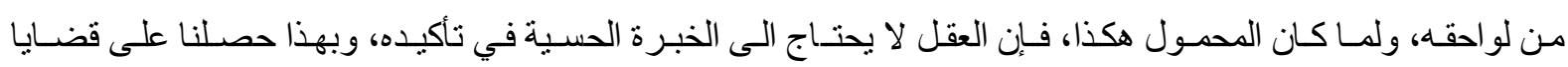
تركيبية، من غير الرجوع الى الخبرة الحسية.

ويمكن القول بـأن كنط، وضـع معيـار اً عامـاً لتمييز القضـايا التحليليـة، عن القضـايا التركيييـة، وهو مبدأ عدم

التنـاقض، فإن صدق هذا المعيـار فالقضية تحليليـة، سواء كان محمولها من ذاتيـات إيسـاغوجي، أو مـن ذاتيـات البر هـان،

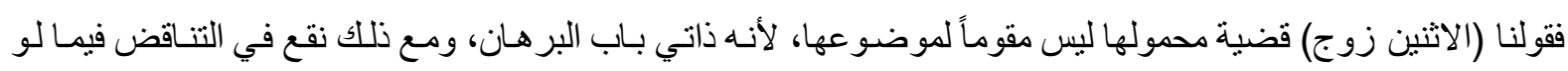

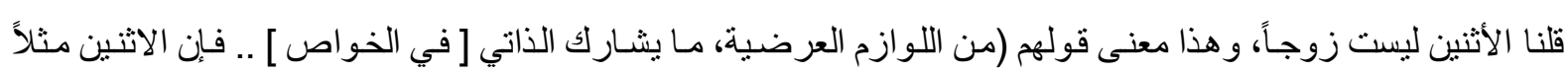

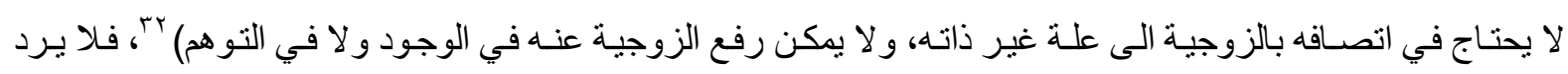

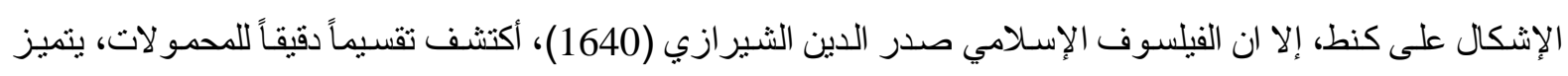
به ذاني البرهان، عن ذاتي إيساغوجي، بحيث تقتصر الإفادة من مبدأ التناقض على ذاتي إيساغوجي فحسب. قال الثبرازي (ان حمل شيء على شيء واتحاده معه يتصور على وجهين، أحدهما: الثنائع الصناعي .. وهو

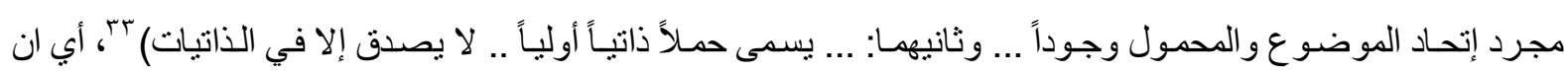

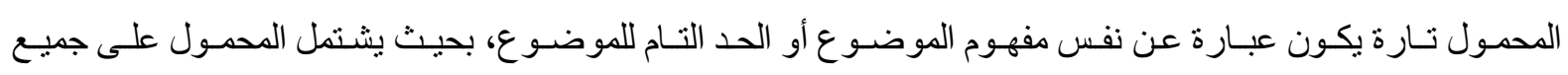

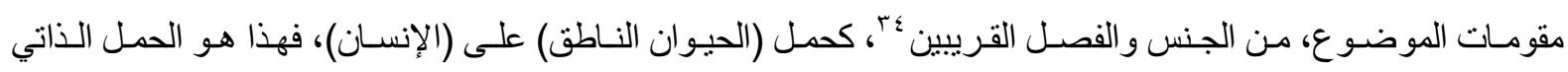

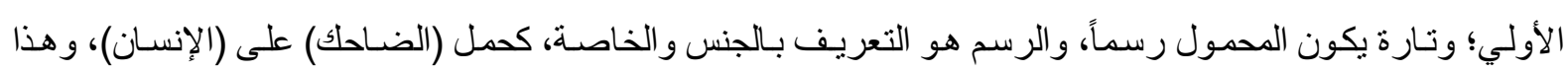

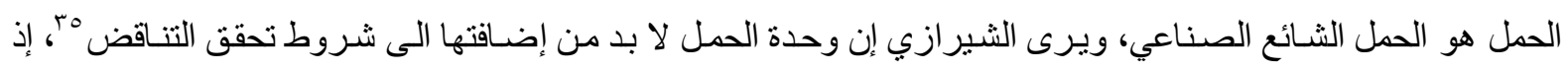
يقول (ولذلك اعتبرت في التناقض وحدة أخرى سوى الشروط الثمانية المشهورة، وتلك هي وحدة الحمل، فـالجزئي مثلاً

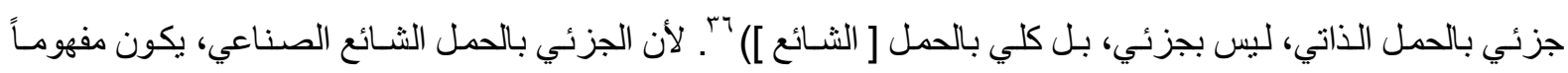
صادق على الجزئيات الخارجية، فيكون من هذه الناحية كلياً. يظهر من كل هذا، إن المحمول في الحمل الذاتي الأولي، هو ذاتي بـاب إيساغوجي فحسب، أمـا المحمول في

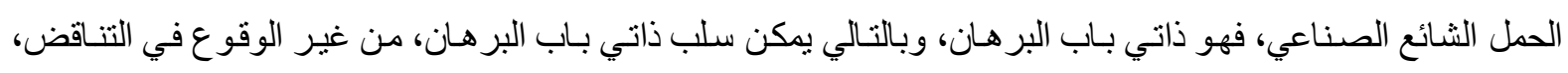

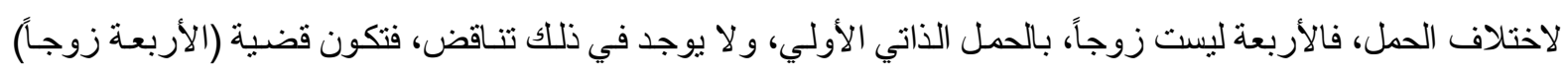

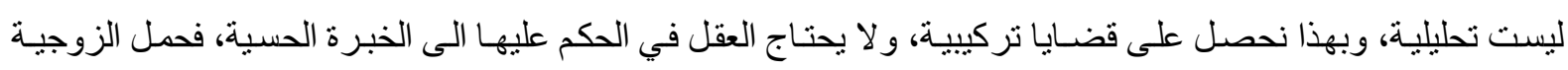
على الأربعة لا يحتاج الى بر هان.

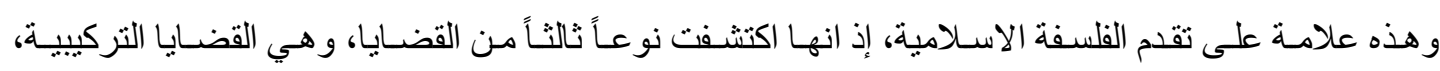

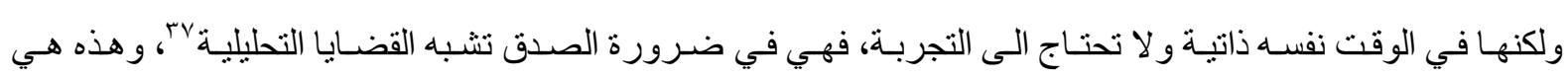

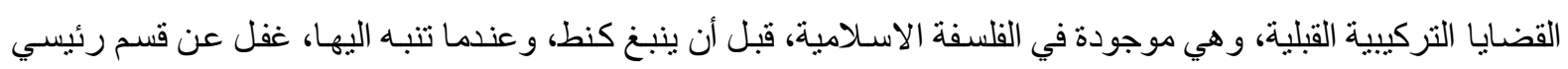

أما المسألة الثانية، فتتعلق بكيفية نشـأة المفاهيم الكلية في العقل البشري، وفي ضو ء السياق الفلسفي الذي صدر

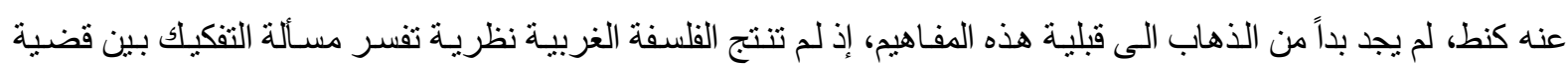

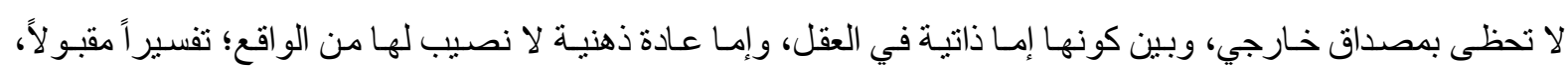


وعقلانية كنط تأبى عليه أن ينقاد لثكوك ديفيد هيوم، الذي أنهى أحكام الضرورة و الكلية الى مجرد عادات ذهنية تنشـأ

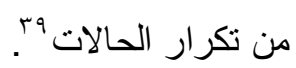

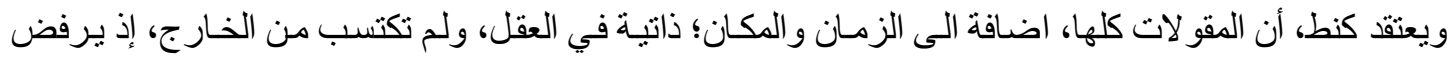
نظريـة التجريد في نشـأة المفاهيم الكلية، لأن مفهوم المكان مثناً، حينما يتأملـه العقل لا يجده (أفهومـاً سياقياً، أو كمـا يقال

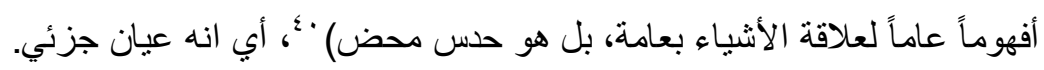
ومن المحققين من يرى ان كنط فهم نظريـة التجريد، على طريقة المذهب الحسي، إذ المذهب الحسي لا يرى في

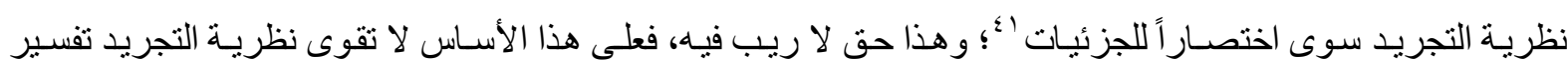

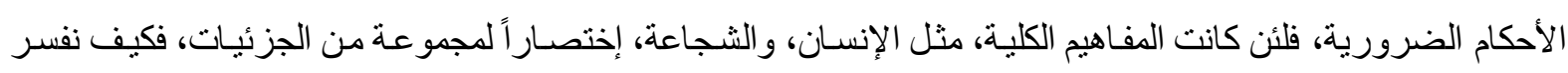

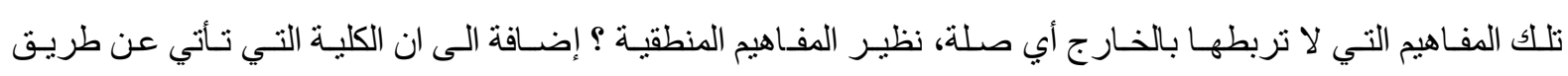

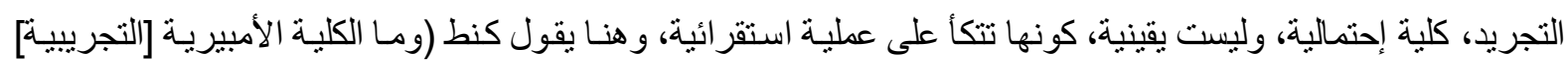

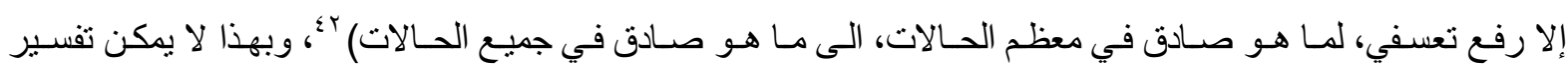
الضرورة إلا عن طريق المفاهيم الذاتية.

أمسا في الفلسفة الاسـلامية، فالمعرفة كلها مكنسبة، إذ ترفض فكرة المعارف الفطرية، فالعقل في بدايته صفحة

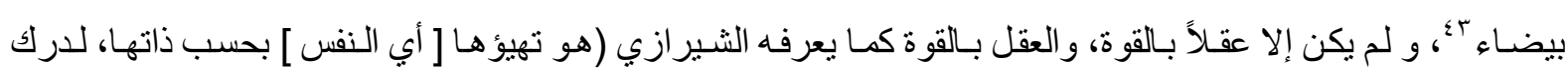

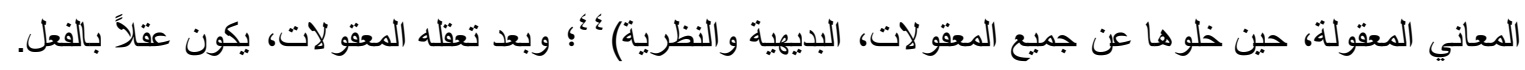
و المعقو لات، تكون على قسمين: أولى، و ثانية، أمسا المعقو لات الأولى فهي تحكي عن أقسـام الوجود، بينـا تعبر

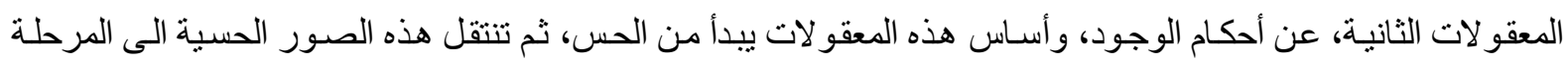

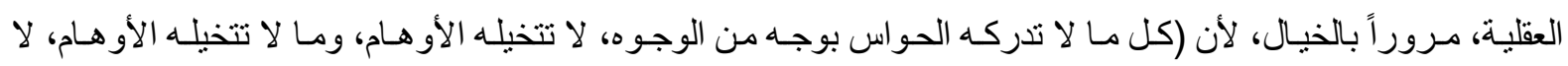
تتصوره العقول)؛

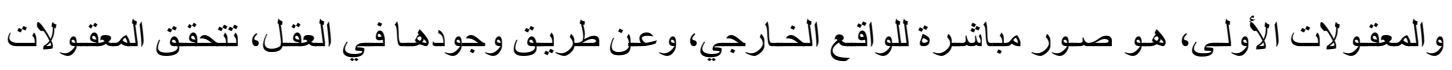

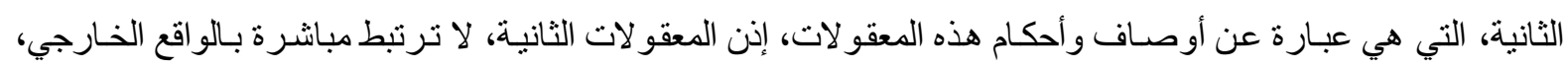

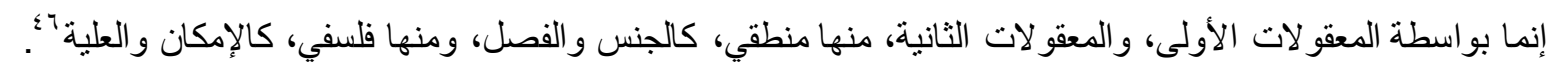
إذن هذاك مفـاهيم في العقل، لم تنشـأ فيسه بصـورة ذاتيـة، وفي الوقت نفسـه، لا يوجد لهـا مقابـل موضـوعي في

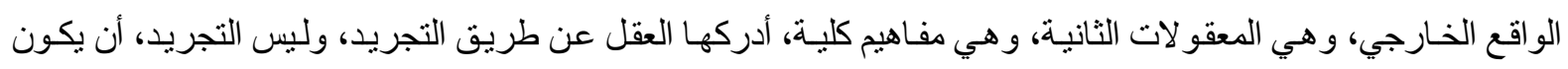

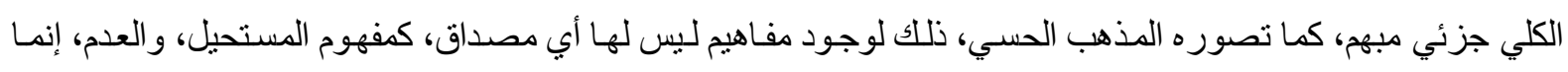

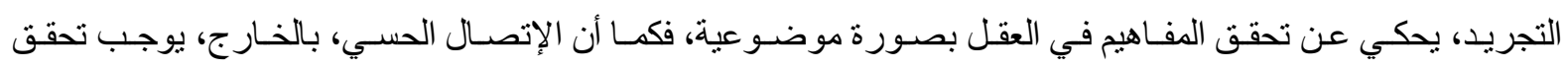

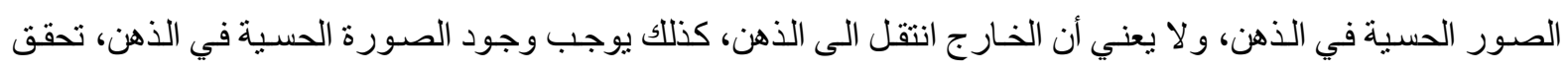

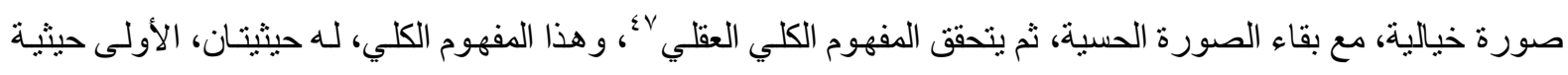

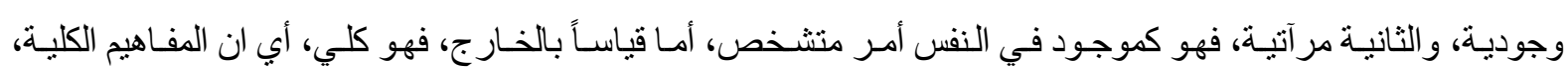

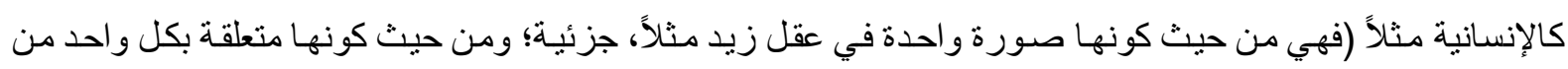

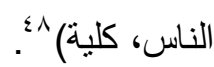


وتبعـاً لنظريـة التجريد، فإن المعقول مرتبط بالمسـوس، إذ المفـاهيم الكلية منتزعـة من الأمسور الحسية، الأمـر

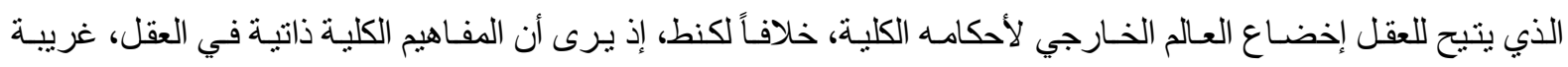

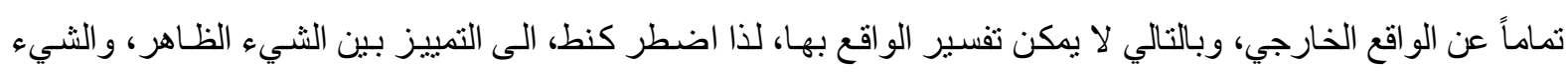

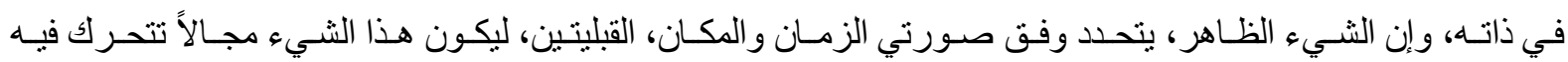

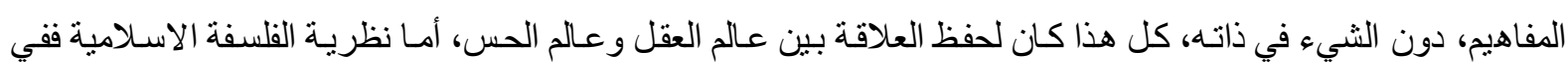
غنى عن كل ذللك.

وبهذا يمكن تفسير كيفية نشوء المفاهيم، بما لها من كلية، وضرورة، من غبر افتر اضهها ذاتية في العقل، أمساقول كنط، بـأن ارتباط العقل بالخـارج، يكون عن طريق الاستقراء، والأخير ليس بقادر على إعطاء اليقين، فغير وارد، لأن

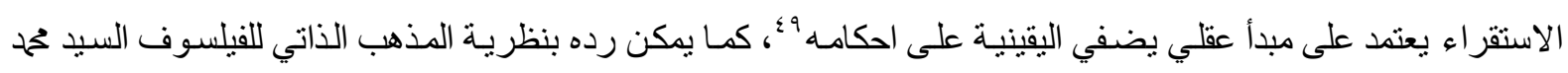

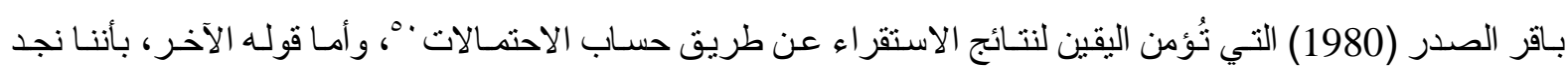

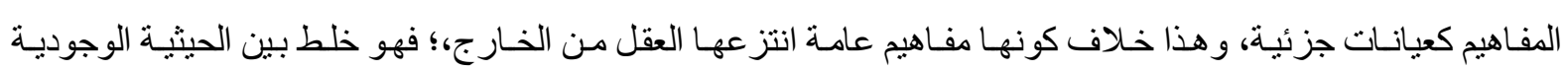
والحيثية المر آتية، للمفهوم. وهنا يحسن الحديث عن أمرين:

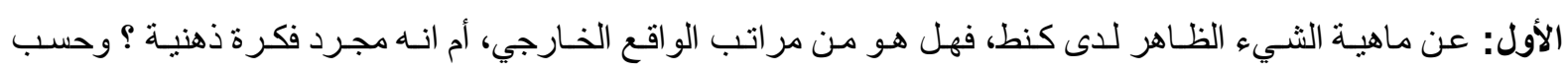

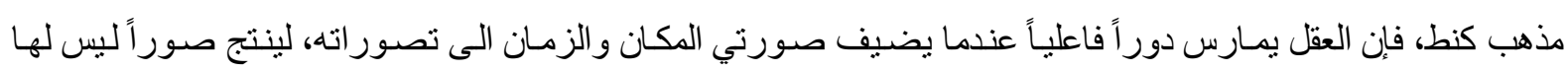
خارج حدود العقل أدنى وجود، وفي هذا السياق يقول جوستان غـاردير في وصف فلسفة كنط ( ليس شعور الإنسـان

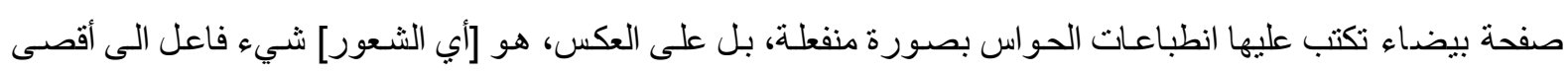

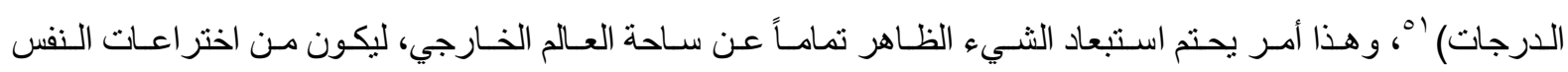

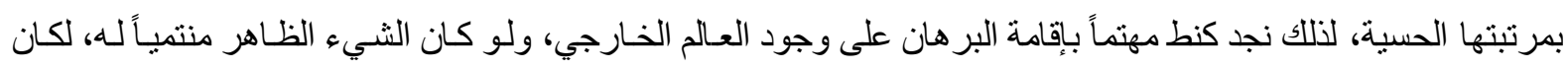

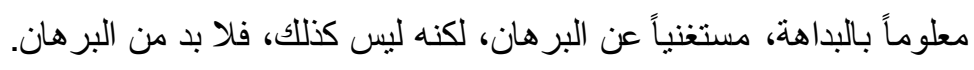
الثاني: عن موقف الفلسفة الإسـلامية من الثـيء في ذاتـه، إذ ميز فلاسـفة الإسـلام بين المعلـوم بالذات، وبين المعلـوم

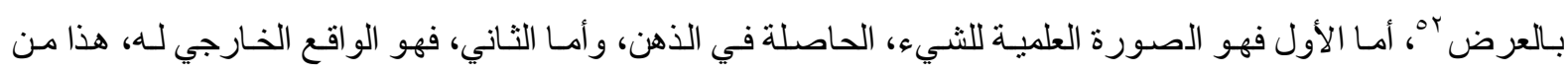

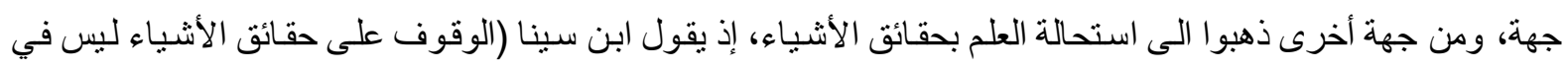

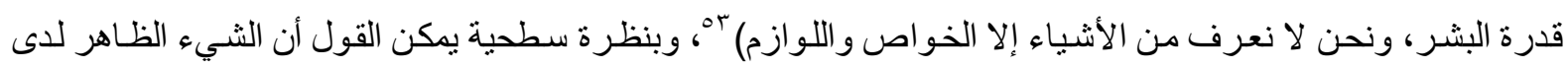

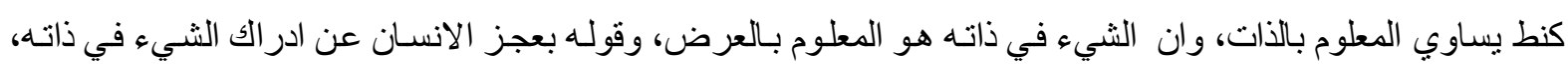

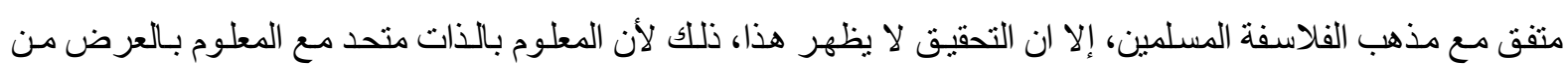

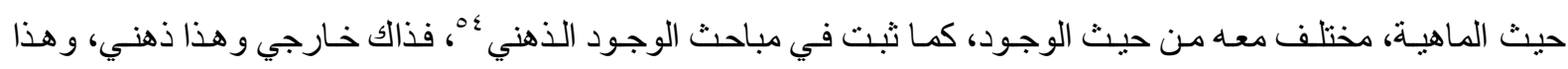

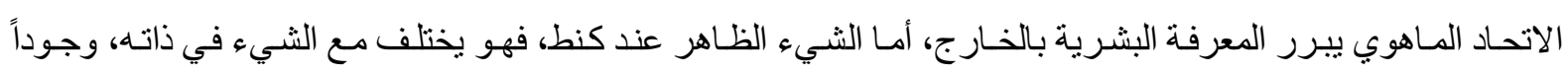

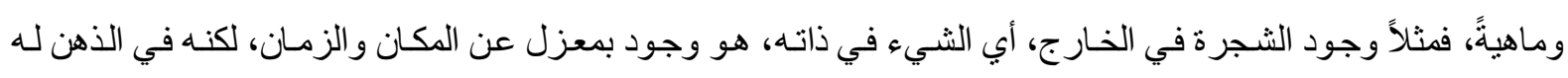

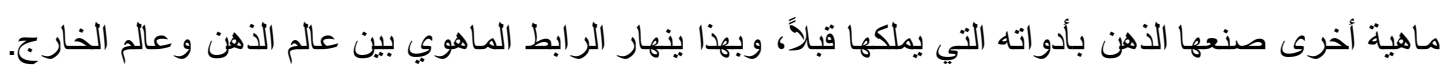
و على هذا الأساس ذهب كنط الى امتتاع ادر اك الثيء في ذاته، و هذا الامتتاع نتيجة ضرورية لانفصسام عرى

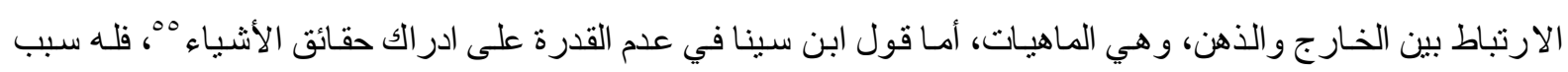


آخر ، ققد ثبت أن العلم بالعلـة علـة للعلم بـالمعلول، ولو عرفنـا حقائق الأشياء لعرفنـا لوازمها القريبـة والبعيدة، من دون

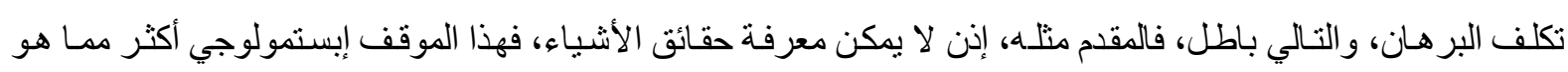

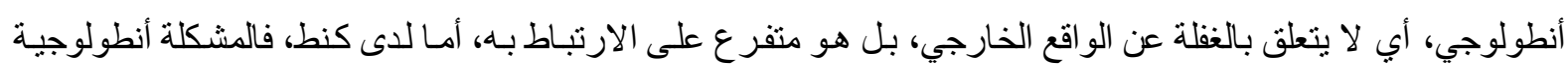

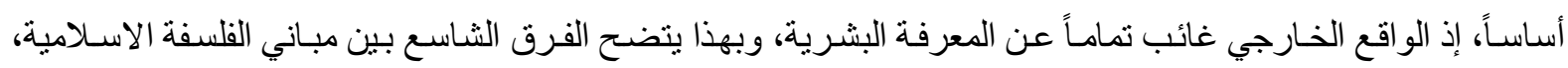
وبين مباني الفلسفة النقدية.

أما فيما يتعلق بالمسألة الثالثة، و هي دحض المثالية من قبل كنط، ليثبت و اقعيـة العالم الخـارجي، وكما تقدم فبان

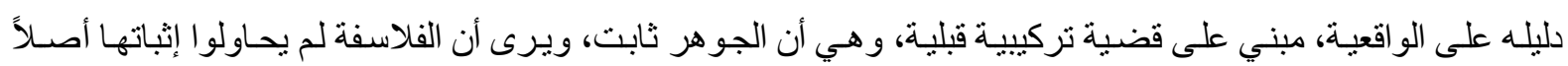

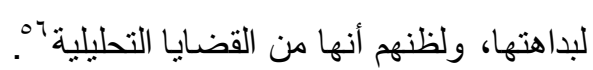

و الحق، ان الفلاسفة لم يعتبروا قضية الجوهر ثابت، قضية تحليلية، بدليل أنهم أقاموا الأللة على إمتناع الحركة

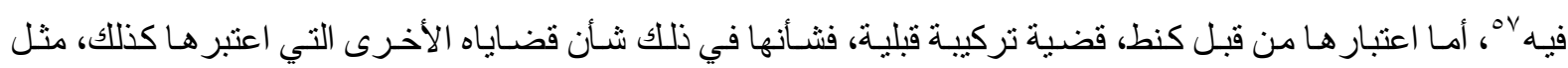
(الخط المستقيم، هو الأقرب بين نقطتين) و (كميـة المـادة ثنابتة) مه، والتي ثنبت خطأهـا فيمـا بعد، إذ كان يعتمد على النظـام

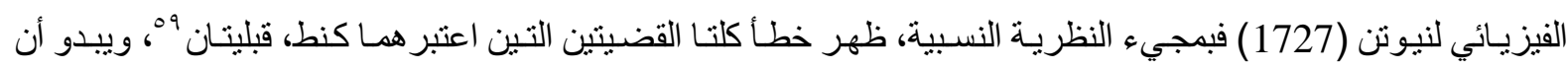
افتر اضه الزمان و المكان، كصورتين منفصلتين عن بعضهما، مستقلتين عن الخارج، أيضـاً كان بوحي من فيزياء نيونن،

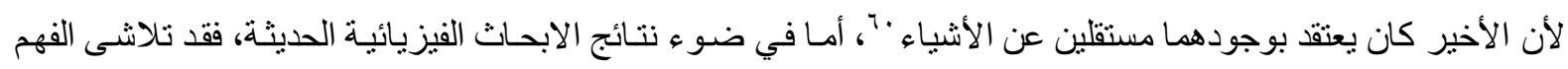

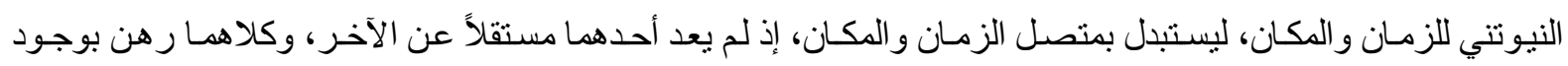

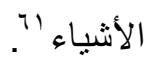

أما قضية الجو هر ثابت، والتي ادعى كنط، قبليتها، فقد حضت من قبل على يد صدر الدين الثبرازي، إذ أثبت

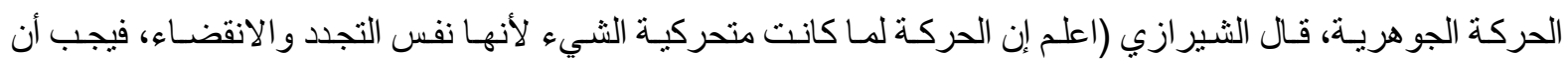

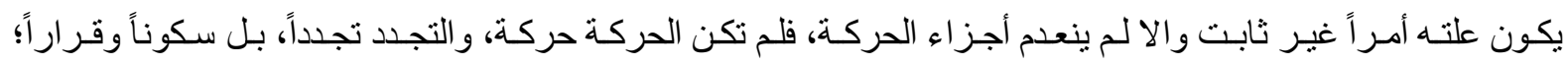

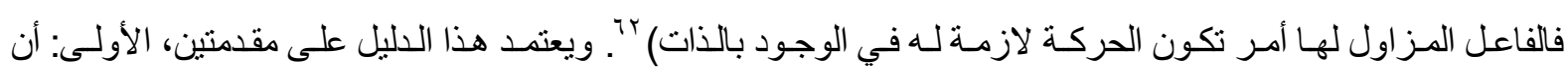

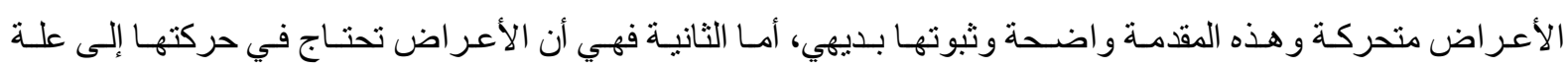

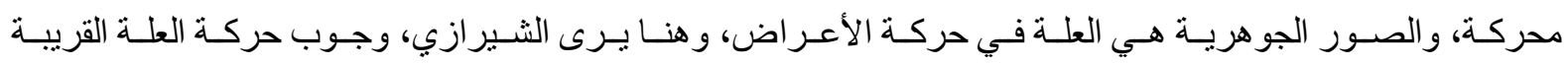

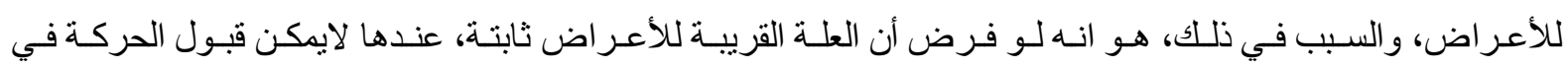

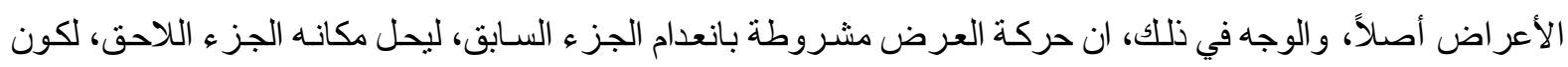

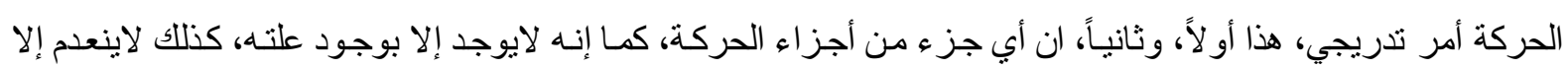

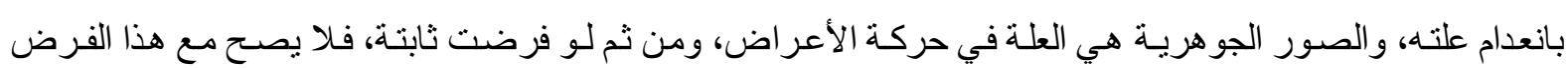
حركة الأعر اض.

وبهذا ينهار البرهان الكانطي على وجود العـالم الخـارجي، هذا فضـلاً عن وجود خلل جوهري في برهانه، وهو

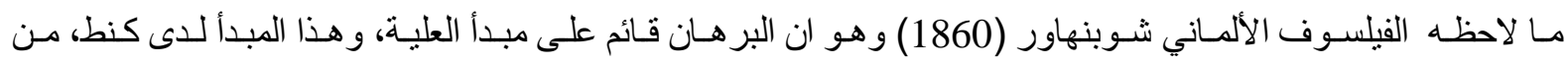

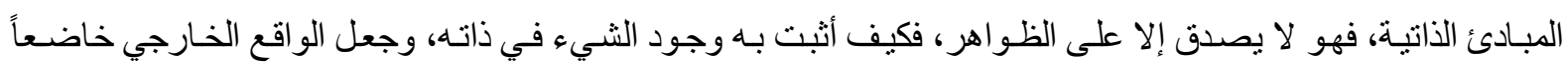

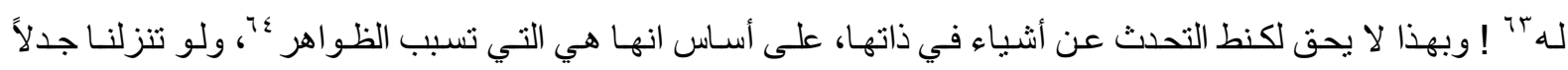


برهان كنط على وجود العـالم الخـارجي، فأي ثـرة تترتب عليه ؟ فسواء كان موجوداً أو غير موجود، فالأمر سيان من

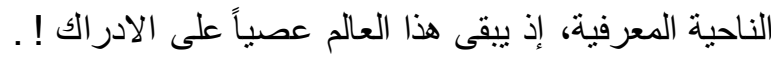

وآخر المسـائل هنـا، تتمثل بموقف كنط السلبي من أدلة الوجود الإلهي، و لا يمكن أن ننتظر منه غير ذلك، لأن مبدأ الواقعية يعد المنطلق الأسـاس لإثبات الوجود الإلهي، وكما سبق فيان هذه المبدأ متزلزل جداً في الفلسفة النقديـة. بدأ

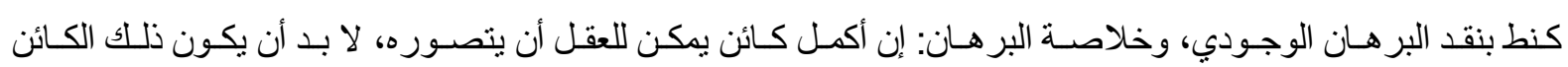

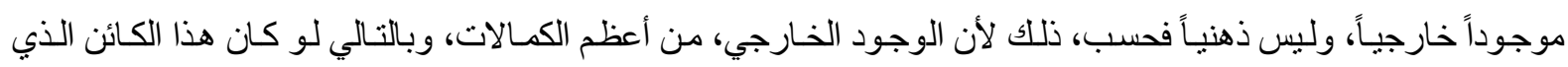

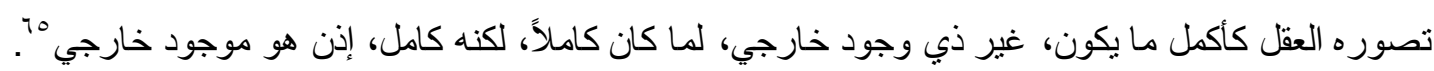
و الو اضـع الأول لهذا البرهـان، هو القديس أنسلم (1109) و عنـه أخذه بونـافنتورا (1274) ثم ديكارت، وليبنتز ، و هيجل (1831) ولم يكن كنط أول من نقده، فقد نقده راهب يدعى جونيلون، وهو معاصر لأنسلم، كمـا نقده القدبس نومـا

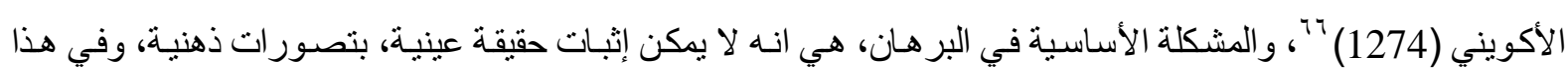
السياق جاء نقد كنط و الجدير بالذكر ان هذا البرهـان لا قيمـة لـه في الفلسفية الاسـلامية، إذ يقول صدر الدين الثيرازي (كل مفهوم

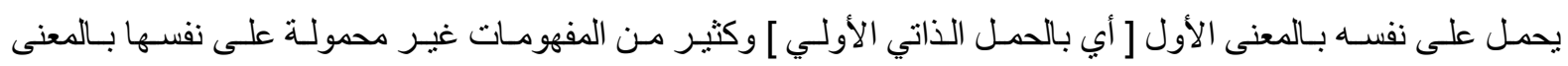

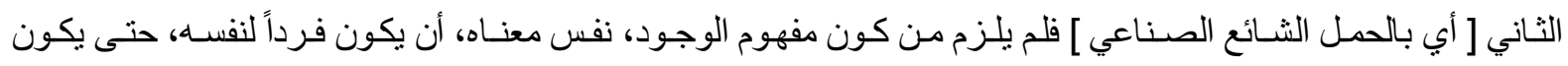

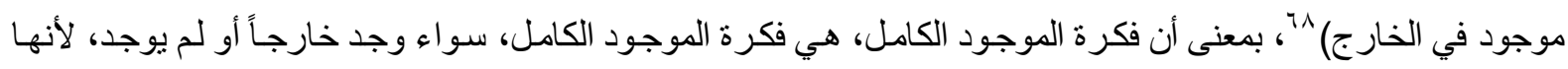

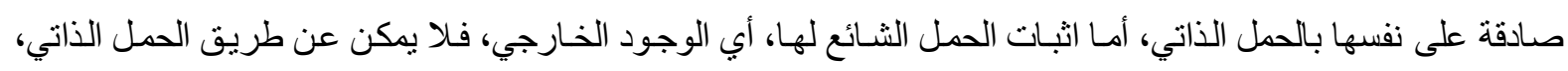
بل بطرق أخرى 19.

ويمتاز البرهـان الوجودي، بكونـه لم يعتمد المنهج الإني، أي المنهج الذي يجعل وجود المعلول، حداً أوسطاً في

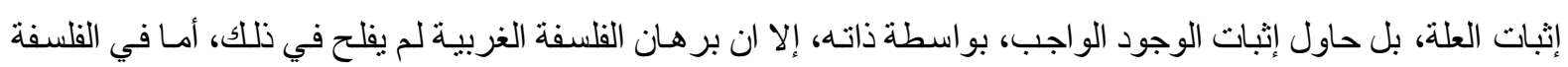

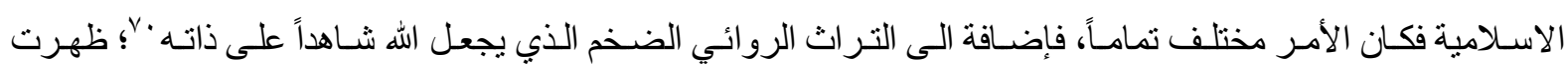

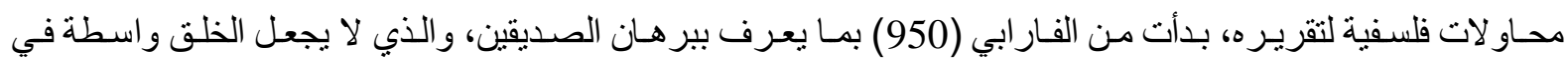

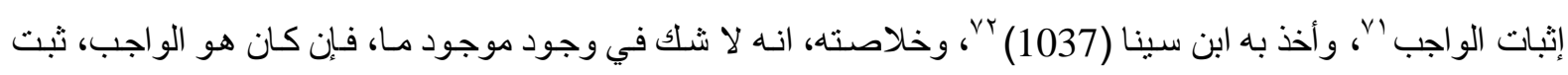

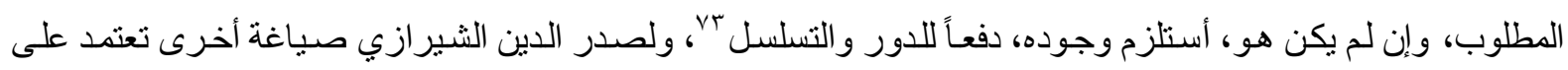

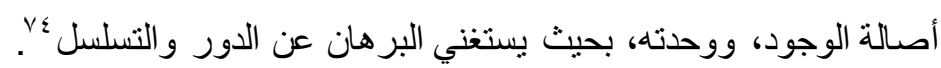

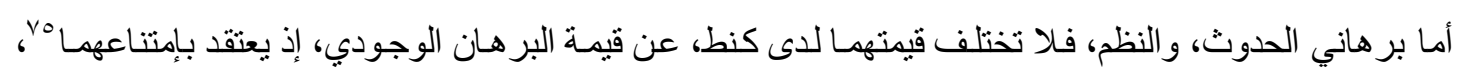

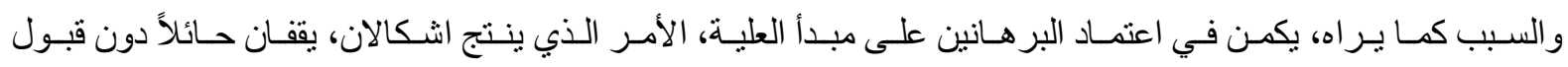
البر هانين.

يقول كنط (1: .. ليس لمبدأ السببية أي مدلول أو معيار، لاستعماله، إلا في العـالم الحسي، و الحسال ان مـا يطلب

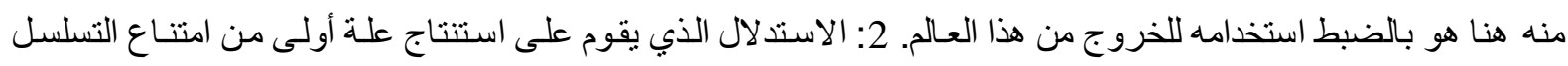

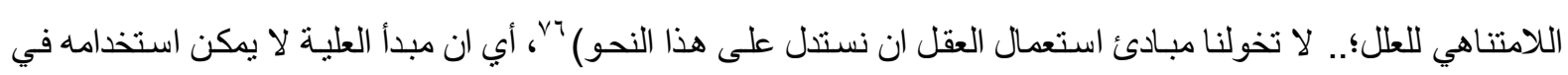

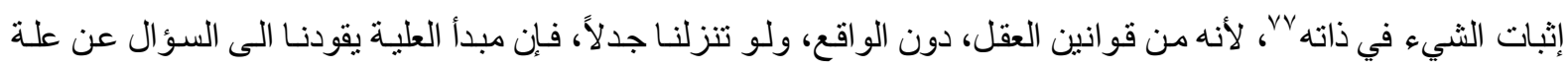

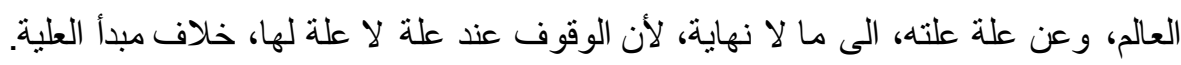


ويمكن رد الاشكال الأول ببساطة، لأن مبدأ العلية، مبدأ واقعي، انتزعه العقل من العـالم الخـارجي، كمـا ثبت في

الفلسفة الاسلامية، وقد تقدم الحديث عنه في المسألة الثنانية.

أما الإشكال الثاني، فهو ناشئ من عدم صياغة مبدأ العلية بصورة فلسفية صحيحة، فقد تمت صياغته على نحو

الموجبة الكلية، وهي لا يوجد شيء بدون علة، وبناءً على هذه الصباغة، تبرز أمامنا مشكلة التسلسل في العلل، وقد تتبه

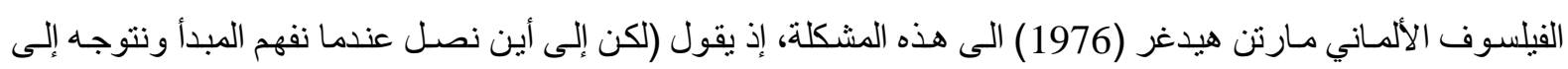

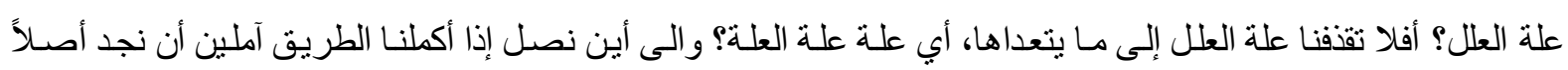

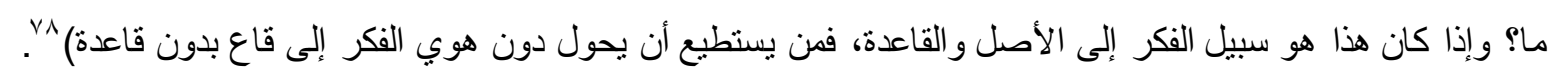
و هذه المشكلة تعود الى غياب مسألة أساسية في الفلسفة الغربية عامـة، وهي مسـالة: مـلاك الحاجة الى علـة، وهذا

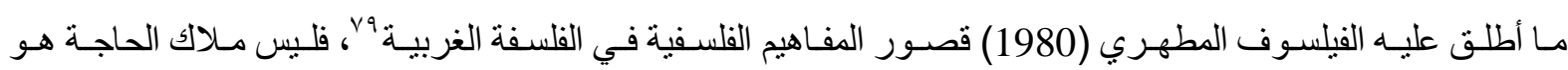
الوجود، إنما الإمكان، وبهذا فالصياغة الصحيحة لمبدأ العلية، هي ان كل ممكن محتاج الى علة، لا أن كل موجود محتاج الى علة، فيمتتع التسلسل بالعلل.

\section{هصادر البحث وهواهشه}

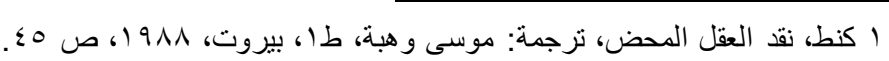

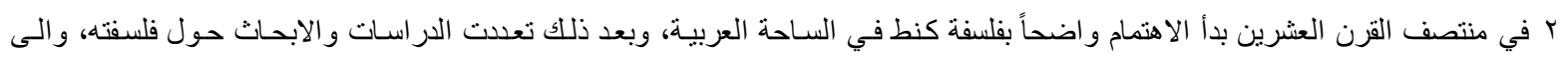

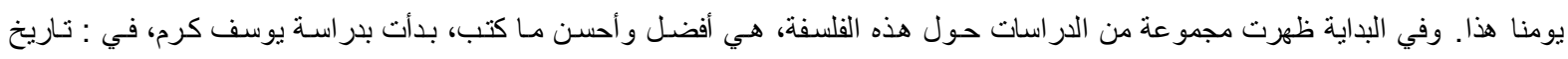

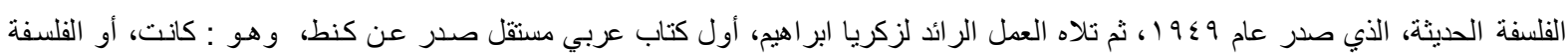

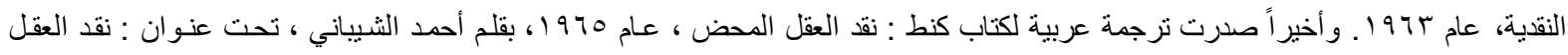

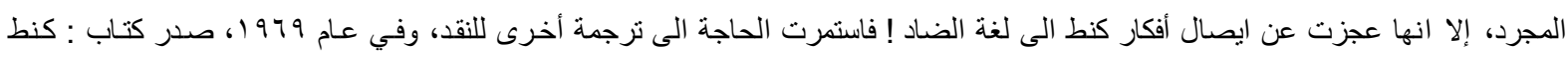

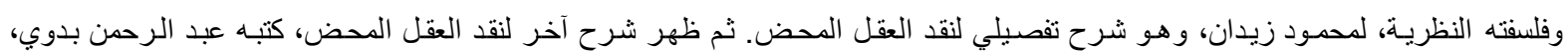

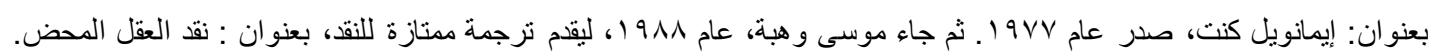

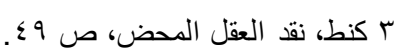

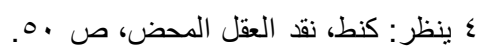

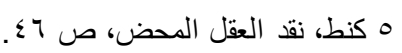

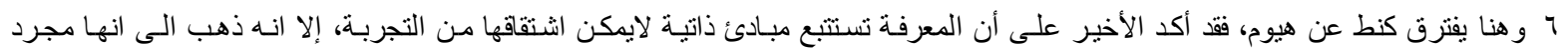

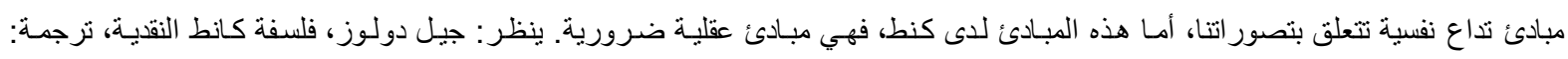

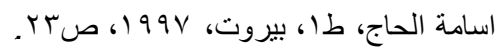

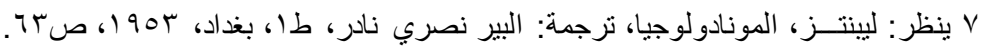

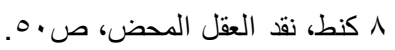

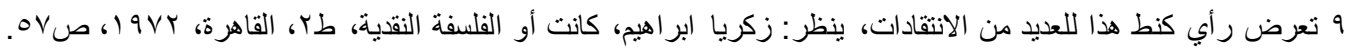

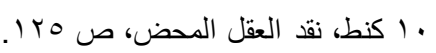
(ترجمها عبد الرحمن بدوي : الذهن . فيما ترجمها موسى وهبة : الفاهمة . derVerstand II

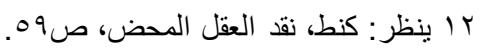

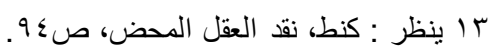
ع ا ينظر : كنط، نقد العقل المحض، صنط

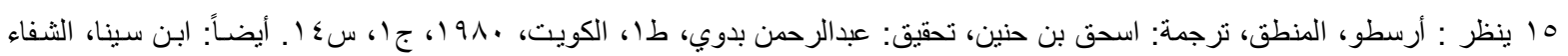

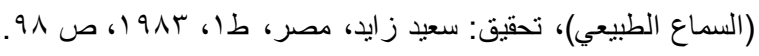


9

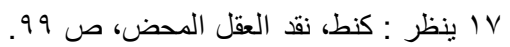

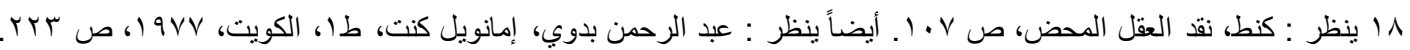

19 19

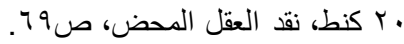

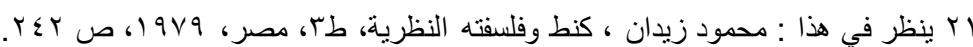

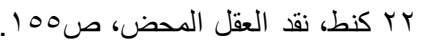

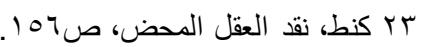

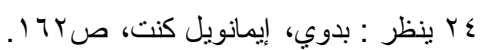

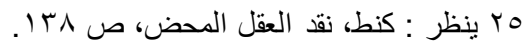

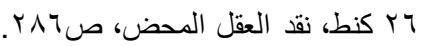

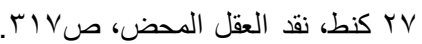

N تعرضت فلسفة كنط، الى لونين من النقد، نقد جاد، له أسسه الفلسفية، وآخر ليس كذللك، أمسا الأول، فنجده مثناً عند، برتر اند رسل، ينظر :

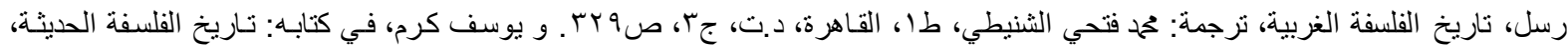

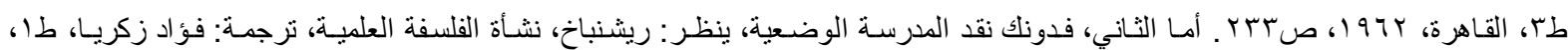

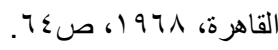

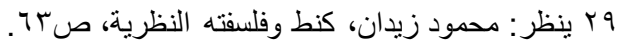

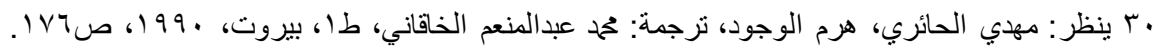

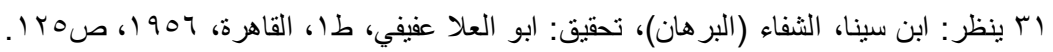

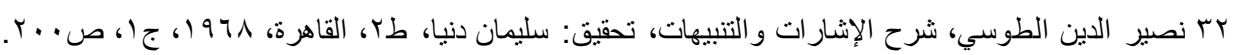

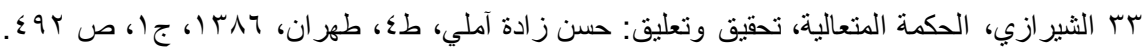

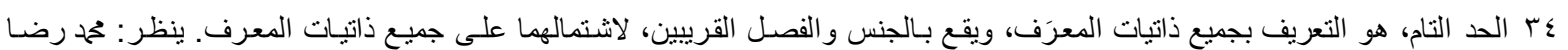

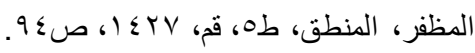
هب وهي ثمانية : وحدة الموضوع، المحمول، الإضافة، الثرط، الزمان، المكان، الكل والجزء، والقوة الفعل. ينظر: الحلي، الجوهر النضيد، ،

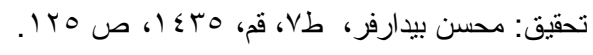

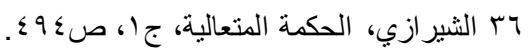

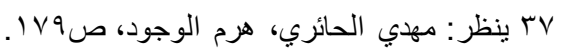

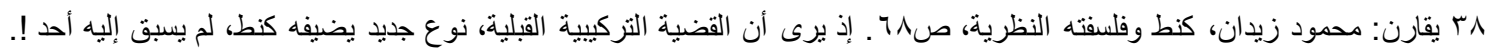

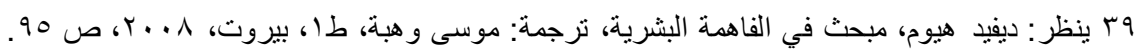

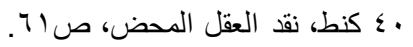

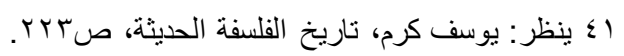

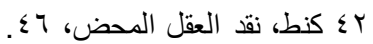

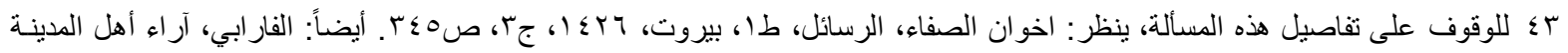

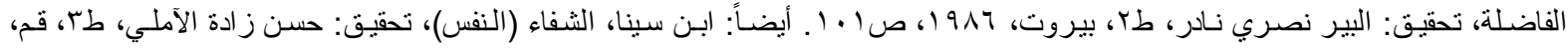

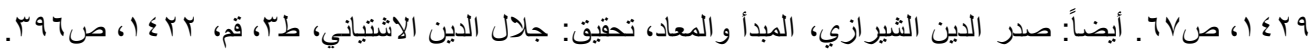

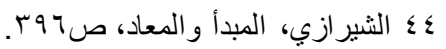

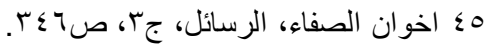
7

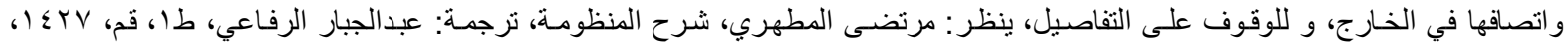




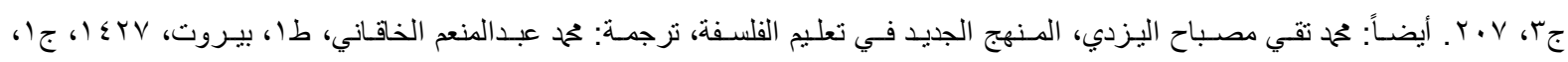
.1100

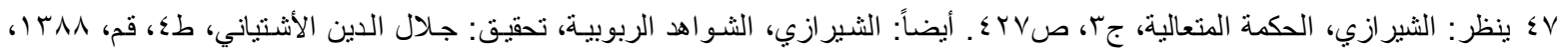
ص

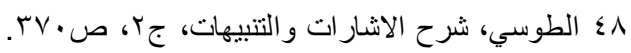

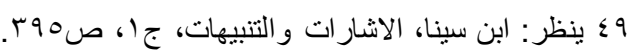
•

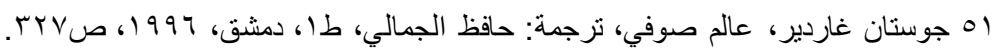
ror

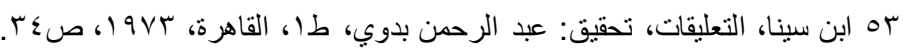

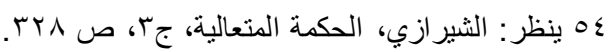

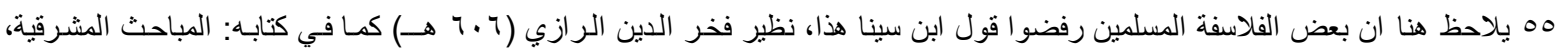

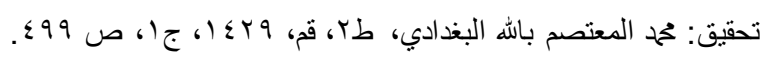
إنظ

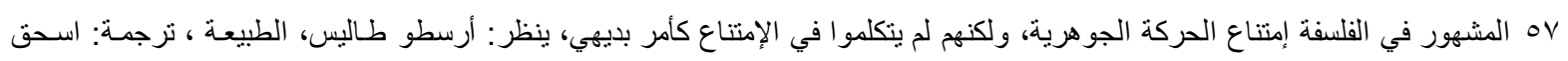

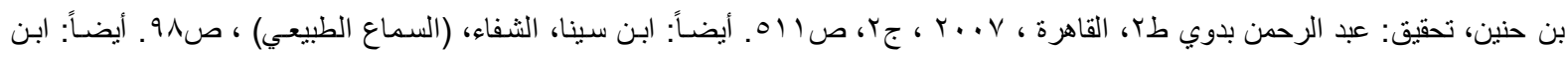

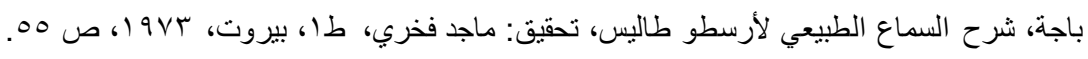

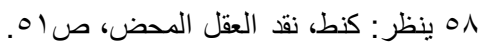

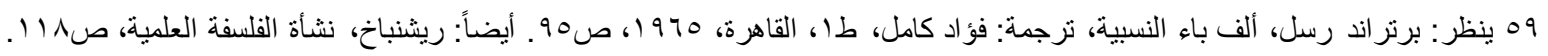

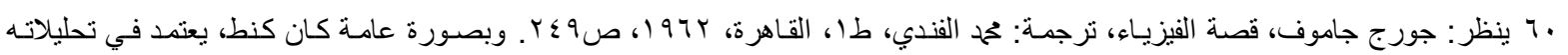
على الهندسة الإقليدية، بيد أن العلم وصل بتطوره الى اكتشاف هندسات أخرى غير إقليدية.

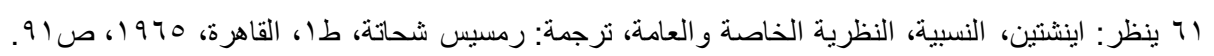

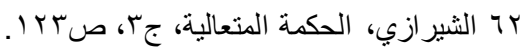

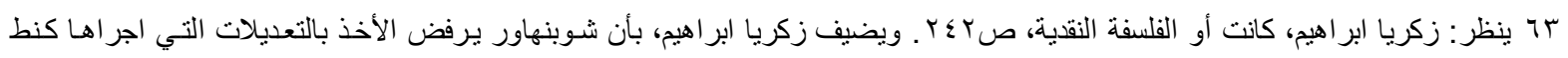

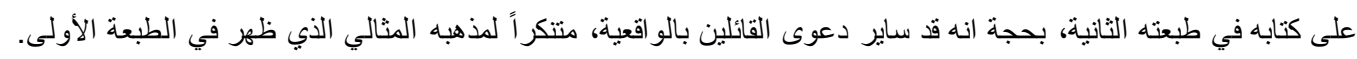

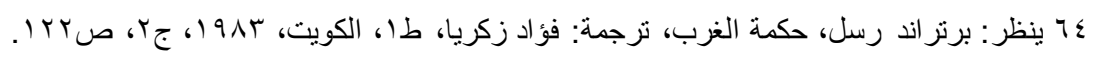

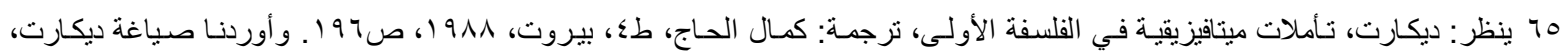

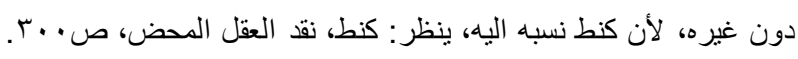
T1 للوقوف على هذا البر هان عند القديس أنسلم، وتفاصيل نقد الراهب جونيلون، ورد القديس أنسلم عليه، وكذا نقد نومـا الأوكيني، ينظر : نمـاذج

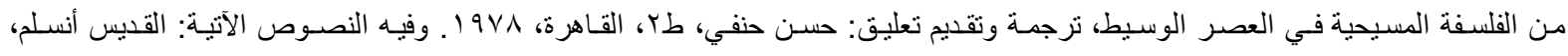

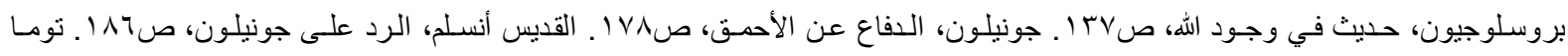
الأكويني، الوجود و الماهية، صبكبr.

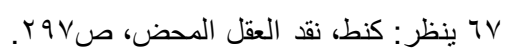

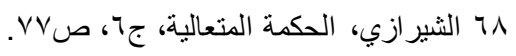

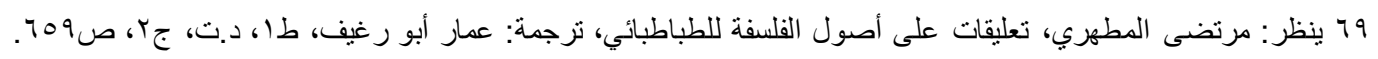

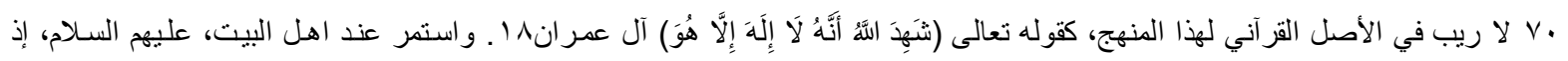
يقول الامام الحسين، سلام الله عليه، في دعاء عرفة والذي رواه ابن طاووس (1266) (كيف يستدل عليك بمـا هو في وجوده مفتقر اليك، أيكون

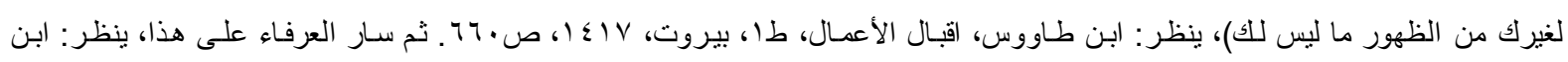




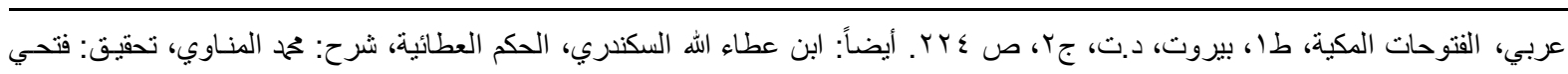

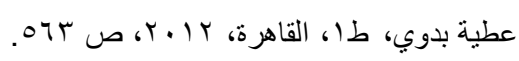

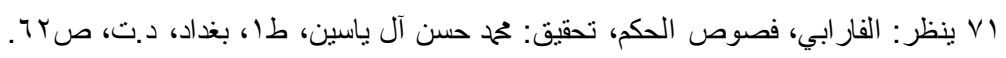

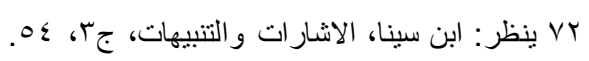

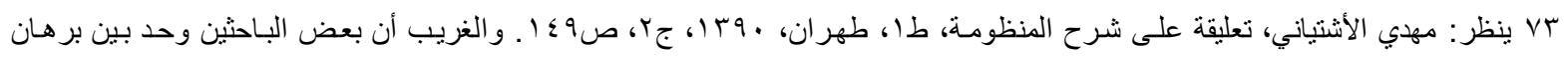

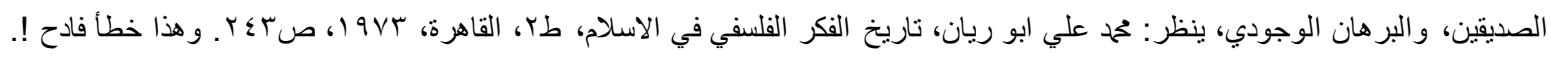

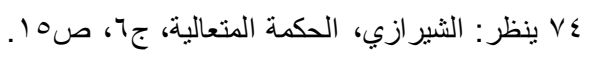

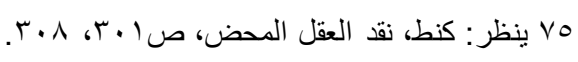

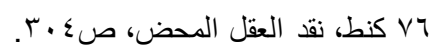
وV و هنا تناقض و اضح من قبل كنط، فقد سبق و أن أثبت العالم الخـارجي بمبدأ العلية، من غير مر اعـاة كونـه مبدأ ذاتي، أمسا هنـا فـلا يجيز

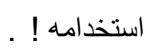

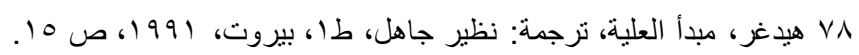

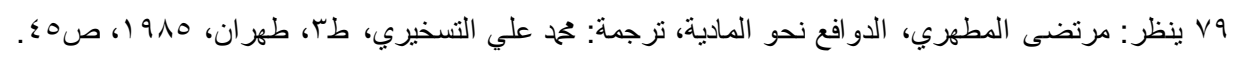

